\title{
Historein
}

Vol 16, No 1-2 (2017)

Greek Historiography in the 20th Century: Opening a Research Agenda

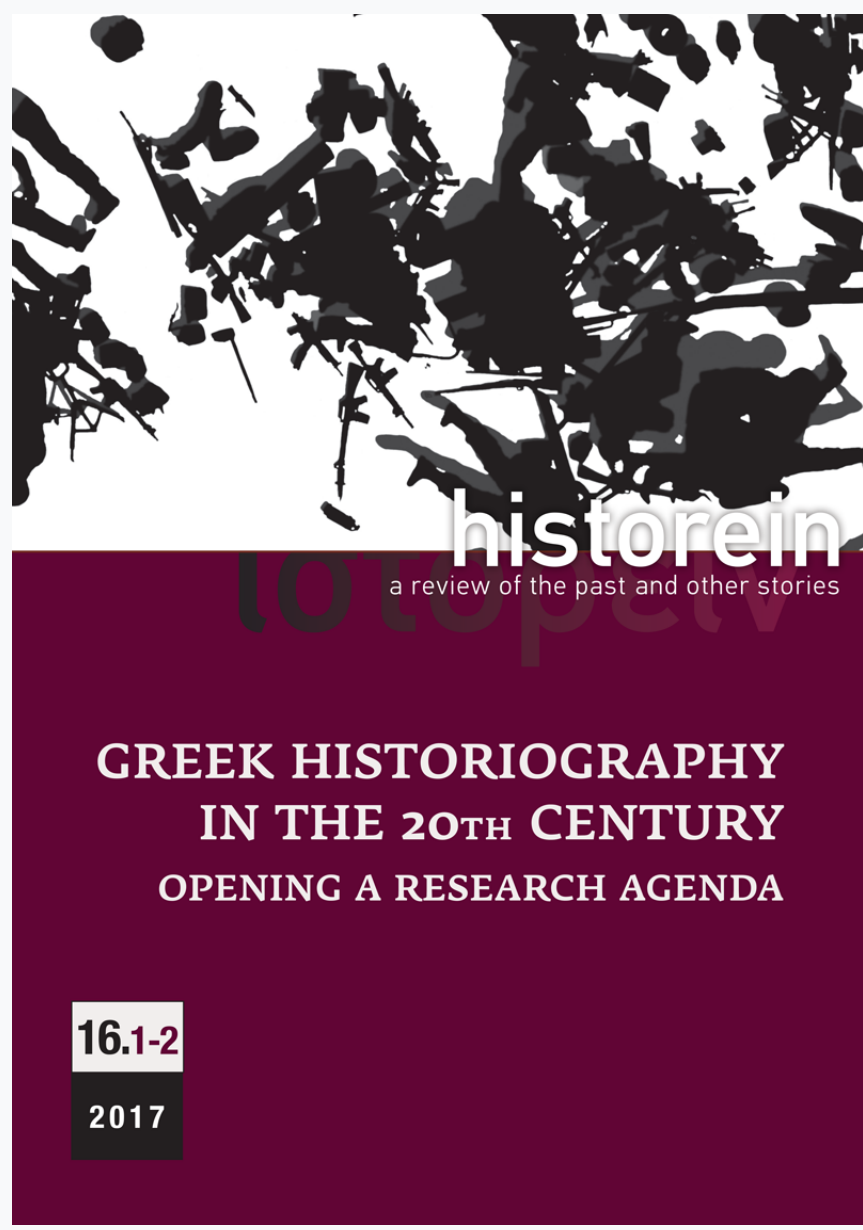

The historiography of the Greek Diaspora and migration in the twentieth century

Lena Korma

doi: $10.12681 /$ historein. 8778

Copyright @ 2017 , Lena Korma

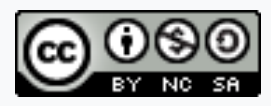

This work is licensed under a Creative Commons Attribution-NonCommercialShareAlike 4.0.

To cite this article:

Korma, L. (2017). The historiography of the Greek Diaspora and migration in the twentieth century. Historein, 16(1-2), 47-73. https://doi.org/10.12681/historein.8778 
The aim of this article is to provide a critical overview of the literature on Greek diaspora and migration in the twentieth century. Migration and diaspora studies, comprising various disciplines and offering diverse interpretations, have become quite extensive. Migration and diaspora are approached in an increasingly detailed, complex and multilayered manner. At the same time, the radical changes in the last three decades regarding population mobility, the geopolitics of diaspora communities, the exacerbation of nationalism and the modification of the rules for granting citizenship, are also affecting migration studies. Consequently, the purpose of this contribution is not to provide a general account of the migration-diaspora phenomenon.

On the contrary, we will attempt to offer a historiographical approach, focusing mainly on Greek language literature and, in particular, on works that have served as landmarks for Greek migration studies. We will focus on emblematic works that reflect ruptures and continuities, and that highlight the shift and debate around special terminology, given that the use of terms such as apodimos, apoikia, paroikia or repatriations is subject to controversy and political ambiguity. Countries such as Australia and Canada, as traditional host countries for Greek immigrants, have their own literature on the subject. However, with the exception of a few references to important works mainly from Greek-American literature, this article will not focus on those countries. Despite the strong presence of the subject of Greek migration in cinema, literature, music and other forms of art, this article will not consider these aspects either. Rather, our purpose is to demonstrate the shift in the scope/ paradigm that can be observed in the Greek-language literature. By focusing almost exclusively
The historiography

of the Greek

diaspora and

migration in the

twentieth century

\section{Lena Korma}

French School at Athens

There has been a Homo migrans for as long as Homo sapiens has existed, since migrations are as much part of the human condition as birth, reproduction, sickness and death.

—Klaus J. Bade, Migration in European History, trans. Allison Brown (Malden: Blackwell, 2003), ix. 
on Greek historiography, we will attempt to illuminate the political changes in Greek society and the broader ideological shift in social sciences. A brief overview of the Greek migration history in the twentieth century will allow readers to better understand the developments in Greek historiography.

Migration in modern Greek history is not an exclusive phenomenon of the twentieth century. Throughout the entire period of Ottoman rule, Christian subjects, mostly of Greek origin, maintained close ties with foreign places: with Venice from the fifteenth century; with Central Europe from the seventeenth and more systematically in the eighteenth centuries, and with southern Russia and Egypt towards the end of the eighteenth and mainly in the nineteenth centuries.' As we will see below, the permanent presence of Greeks in these regions during that period ${ }^{2}$ would incite the interest of a significant number of Greek historiographers of the twentieth century, especially in the post-junta period (Metapolitefsi). ${ }^{3}$ Accordingly, from the eighteenth century, and more systematically in the nineteenth century, there were significant Greek waves of migration from the Greek lands to Asia Minor, bringing about significant demographic and spatial changes to their new areas of settlement. ${ }^{4}$ Though we will return to this subject latter below, it is worth mentioning at this point that a debate started among some historians in the post-junta period over whether the "Kath' imas Anatoli" (the Greek East) forms part of the Greek diaspora or not.

On the other hand, the mass transatlantic migration to America, especially the US, which began in 1890, would change the existing conditions. It represented a new phenomenon in terms of its causes and also the social characteristics of migrants. ${ }^{5}$ This massive wave of migration was largely linked to the commercialisation of Greek agriculture and the financial consequences of the currant crisis, even when migrants were not directly or indirectly involved in the production and export of currants. ${ }^{6}$ At the same time, the Balkan wars, the outbreak of the First World War and the situation prevailing in the Ottoman empire, starting in 1908 with the adoption of the law on the enlistment of Greeks into the Ottoman army, which was then intensified with the first persecutions in 1914, would significantly influence the decision of many Ottoman subjects to emigrate. 'It is estimated that in the period spanning from the late nineteenth century to the adoption of measures to restrict immigration (quotas) in 1924, about 500,000 Greek emigrants had moved to the US. ${ }^{8}$

The end of the Greco-Turkish War in Asia Minor and the subsequent Asia Minor Catastrophe affected migratory flows. However, the developments from 1919 to 1922 had a comparatively low impact on the migration dimension. The particular case of Pontic Greeks was an exception, considering the problems caused by the arrival of refugees to an already exhausted Greek society, which was not prepared to receive them. ${ }^{9}$ Though most refugees settled permanently in Greece, some of them moved to the already thriving community in Egypt ${ }^{10}$ or to France, Australia, Argentina and the US, despite restrictive legislation. ${ }^{11}$ According to Paschalis Kitromilides and Alexis Alexandris, approximately 66,000 refugees from Asia Minor opted to re-emigrate to other countries after passing through Greece. ${ }^{12}$ Nevertheless, it is worth noting that, with a few exceptions, ${ }^{13}$ those population groups did not serve as an individual object of study for historical research in the twentieth century but were instead regarded as part of a broader migratory flow, despite the particular traits that distinguished them from migrants originating from the Greek state. For instance, their inability to return to their homelands may have affected the way they integrated and/ or assimilated. ${ }^{14}$ 
At the same time, the First World War, the Russian Revolution, the Russian Civil War and the withdrawal of tsarist troops from eastern Pontos in late 1917 created an intense forced migratory flow from Pontos to southern Russia and Transcaucasia (Georgia, Armenia, Azerbaijan), while a significant number of migrants headed to Greece in dire conditions. ${ }^{15}$ Nonetheless, it could be argued that, in the interwar years, the three largest communities of the Greek diaspora (Egypt, the US and the Soviet Union) were "forced to deal with a series of measures adopted by host countries, which were designed to achieve a greater degree of social integration of the various ethnic groups".16

The end of the Second World War and the Greek Civil War marks the dawn of a new era for Greek migration. Compared to the transatlantic migratory flows of the early twentieth century, postwar migration was rather a mass phenomenon. ${ }^{17}$ The US continued to be the most popular destination for many migrants, though some of them turned to Africa, Central and South America, Canada and Australia. ${ }^{18}$ At the same time, those who are forced to emigrate for political reasons resorted mainly to the Balkans, Central Europe and the Soviet Union, whereas a second migratory wave of political refugees, clearly smaller in number, appeared during the seven years of the Greek military junta of 1967-74. ${ }^{19}$ However, the largest migratory wave of Greek agricultural emigrants, especially in the 1960s, turned to northern Europe, and especially to the Federal Republic of Germany, in search of employment and "temporary" residence. ${ }^{20}$ In other words, $61 \%$ of postwar emigrants resorted to northwestern European countries. ${ }^{21}$

The collapse of colonialism and the independence struggle initiated by the countries of the socalled "third world" caused some historical Greek diaspora communities to shrink. One example is the community in Egypt, where regime change directly linked to the end of colonialism, coupled with Nasser's nationalisation policies, caused many Greeks to flee in the late 1950s and during the 1960s, according to the traditional historiographical approach. Nevertheless, in his recent book Angelos Dalachanis reassesses the fate of this community, raising new elements about it. ${ }^{22}$ In addition, internal demographic, political and state changes in eastern European socialist countries, and especially in the USSR, had a significant impact on the fate of Greek migrants and political refugees. ${ }^{23}$

Thus, another key feature of this specific period is the phenomenon of repatriation, which acquired a massive and broader character compared to the past. Those repatriations are mainly linked to the conditions prevailing in host countries and their causes vary for each migratory group. The return of Greeks from western Europe, for instance, is attributed to problems caused due to the plunge of industrial production and the economic recession of 1973 in those countries. On the contrary, in the case of political refugees fleeing the Greek Civil War, those reasons may be sought, among other factors, in the political changes of the post-junta period and the end of the Cold War, followed by the signing of special bipartite agreements with host countries (USSR, Bulgaria, Hungary, Czechoslovakia, Poland and the German Democratic Republic). ${ }^{24}$ The collapse of the Soviet Union marked a new wave of so-called repatriations that culminated in the 1990s. 


\section{Migration-diaspora: divergences and convergences in the twentieth century}

Anyone attempting to write about the history of Greek migration is faced with a daunting task considering that a series of individual concepts must be clarified and positioned in space and

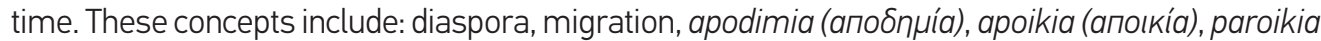

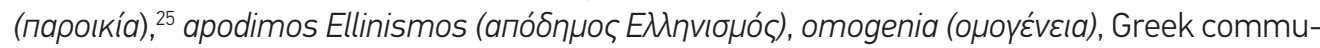

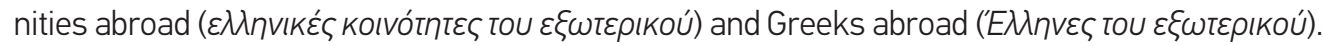
These concepts are not static, as they tend to be transformed, redefined and/or disappear over time. The issues at hand are fundamental and their analysis exceeds the scope of the present article as each separate term could be the subject of an individual study. Nevertheless, we will attempt to discuss some of these concepts by introducing them in their historical context: their use reflects specific trends and landmarks of Greek migration and diaspora historiography throughout the twentieth century. Anna Mandilara has expressed her own concerns in relation to the terms diaspora, paroikies, communities and Greek Orthodox communities, using her research on nineteenth-century Greek merchant-entrepreneurs in Marseille as a starting point. For the author, these terms constitute the "heart of historiographical routes and dead ends" ${ }^{26}$ It would be useful for our analysis to focus on such fundamental notions. However, let us take things from the beginning.

The use of the term diaspora has been discussed both in international and modern Greek historiography. ${ }^{27}$ In recent years, researchers have stressed the need for a critical approach towards and interpretation of the historical evolution of the term, focusing on internal differentiations and conflicts occurring within sending and host countries, both in the moment and over time, so as to gain a better understanding of the complexity of migratory flows and diasporic communities. ${ }^{28}$ The term is an ancient Greek word and its current use originates in the Greek translation of the Hebrew Bible (Septuagint), produced by 70 Jewish scholars from Alexandria (3rd century BC). ${ }^{29}$ As Kitromilides points out, the term "has a density of meaning which is not attributed to its ancient Greek heritage but to the linguistic and stylistic wealth of the Old Testament ... Thus, the term diaspora, passed on through the translation of the Septuagint, became the heritage of 'Christian Hellenism', to borrow a term coined by Konstantinos Paparrigopoulos. ${ }^{130}$ Until the 1970s, the term was exclusively used to designate specific populations, referring to an origin myth or describing a peaceful way of life in the past (for example, ancient Greece or the expansion of Chinese civilisation) or even reflecting the massacres and persecutions suffered by the Jews and the Armenians over the centuries. ${ }^{31}$ However, since the 1970s the use of the term has become established in scientific research.

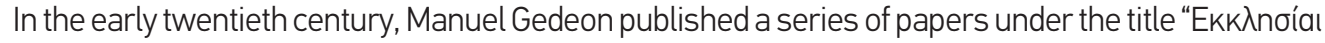

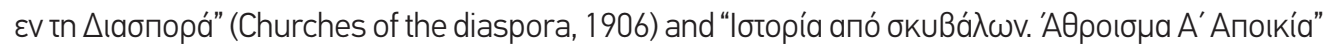
(History of the outcasts, 1916), becoming, as Olga Katsiardi-Hering correctly points out, "the first to talk about modern diaspora, perhaps seduced by the ecumenical character of the term" ${ }^{32} \mathrm{At}$ the same time, according to Michel Bruneau, the autobiographical text of Dimitrios Vikelas published in 1908 under the title $H Z \omega n$ r $\mu$ ou (My life), describes what it means to be part of the diaspora, using

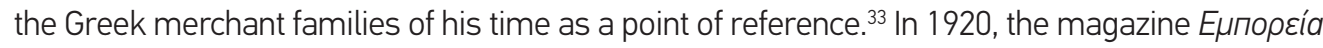
A $\operatorname{\eta nvúv}$ (Athens Commerce) published a series of translated texts, written by the German historian

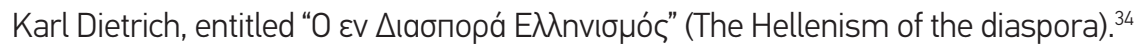




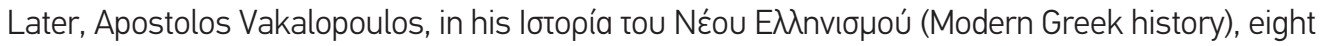
volumes of which have been published since 1960, touches on the issue of Greek mass emigration to central Europe from the fifteenth to seventeenth centuries ${ }^{35}$ and the Greek apodimies to Asia Minor, the Ionian Islands and southern Russia from 1774 to $1783 .{ }^{36}$ The author also uses the same term to describe internal migration in Asia Minor. ${ }^{37}$ The chapter "Greek diaspora in the Balkans" also includes the Phanariotes of the Danubian principalities and the Greeks of Bulgaria and Serbia. ${ }^{38}$ Furthermore, in 1971, during the dictatorship, in his inaugural speech for the celebration of the 150th anniversary of the Greek Revolution, Dionysios Zakythinos attempted, among other

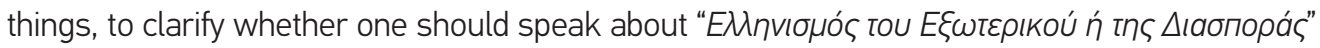
(Hellenism abroad or Hellenism of the diaspora). ${ }^{39}$ After the fall of the dictatorship, a special chap-

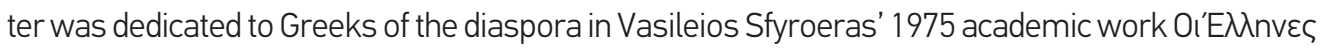

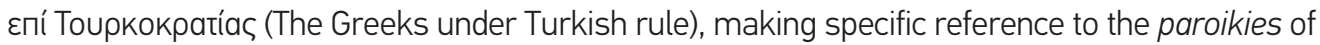
Venice, Livorno, Austria, Hungary and the Danubian principalities. ${ }^{40}$ On the other hand, in a chapter dedicated to the evolution of the Greek diaspora, as included in his 1977 work E乡áptnon kaı Avaпараүwyń (Dependence and reproduction), Konstantinos Tsoukalas also refers to the Greeks of Asia Minor under Ottoman rule from 1830 to $1922 .{ }^{41}$ In respect of this issue, in his critical review of Greek historiography in the post-junta period, Antonis Liakos notes that:

In Greece one basic topos of the national ideology but also of historiography is the history of the Greek Diaspora. Historians of the Greek Enlightenment considered Diaspora as a level of modernisation. But in the history of the nineteenth century its modernisation role was doubted. Of course, the term "Diaspora" changes according to the particular role. If one adopts a position consistent with the ruling national ideology, the issue appears simple: those living in territories where the Greek state was considered ancestral were "unredeemed"; those outside were emigrants. In this way, the point of view of the nation-state is extended to the past. From the moment of its creation, the Greek nation-state rearranged space into three concentric circles: a national centre, an irredentist periphery and the Diaspora. If however, the Eastern Mediterranean is imagined as an area of overlapping ethnic Diasporas, the perspective changes. ${ }^{42}$

In the post-junta period, the first international conference on the "Greek diaspora from the ancient times to date", held in 1988 under the auspices of the Greek president, Christos Sartzetakis, represents a landmark for Greek historiography. Many speakers made explicit or implicit reference to the existence of a diachronic continuity of the term diaspora. ${ }^{43}$ The conference took place in two locations: in Montreal, Canada, for presentations related to the period spanning from antiquity to 1453 and in Athens for contributions on the modern era. In his paper, as included in the first volume, Michail Sakellariou characterised the diaspora as "one of the constants of Greek history from the Mycenaean period to date; a constant that is uninterrupted and of great magnitude. Its causes, the feelings of emigrants and of those they left behind, the psychological profile of the former, the individual and collective success of the Greeks settled far from their national environment, the fate of their descendants, are also characterised by continuity." 44 In his introduction to the second volume, comprising papers on the post-1453 period, John M. Fossey highlighted the term's unity in its dimension over time, by stressing that what differentiates the two volumes is not the subject of the work per se but the methods and approach followed in each case. For Fossey, the study of the

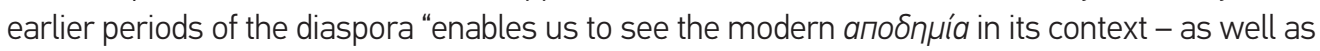


emphasising once more the fundamental continuity of so much that is Hellenic - and study of the contemporary situation can allow us - by cautious retroactive extrapolation of ideas and concepts to achieve a potentially fuller estimation of the earlier stages." ${ }^{45}$

The publication of two works, a monograph by loannis Hassiotis in 1993 entitled Eпıбкónпбоn тnऽ

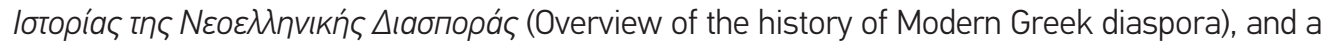
collective volume by Richard Clogg, The Greek Diaspora in the Twentieth Century in 1999 (followed by a Greek translation in 2004), is regarded as a milestone for Greek historiography. In the first chapter of his book, Hassiotis notes that:

The term Diaspora - which, despite its Greek etymology, has its roots in the Old Testament - is used to generally designate the part of the Greek population which, though expatriated for various reasons in order to settle, not always permanently, in countries or areas located outside of the Greek national space, has continued to maintain in various ways its material, cultural or merely emotional links to its birthplace and the country of its direct or older origin. ${ }^{46}$

Hassiotis distinguishes himself from the "romantic perception that the history of the Greek diaspora has been continuous and undisrupted from the first ancient settlements to date", ${ }^{47}$ and divides the history of the Greek diaspora into three broad periods. The first, spanning from the late fourteenth century until the establishment of the Greek state, comprises the voluntary or forced migrations that took place beyond the geographical borders of the Ottoman empire. The second period covers the years spanning from the establishment of the Greek state until the outbreak of the Second World War. Finally, the third period covers the post-junta period, to which Hassiotis dedicates two separate chapters on migration for educational purposes and repatriation. Hassiotis studies the causes and conditions of migration, its consequences for the Greek state, the organisational structures of host countries and the ways in which national consciousness was managed.

For his part, Clogg also distinguishes himself from historians who "refer to these Ottoman Greeks rather loosely as Greeks of the diaspora. But strictly speaking, the Greeks of the Ottoman empire did not form part of the diaspora." ${ }^{48}$ In other words, on the basis of the criterion of voluntary or forced migration, Clogg opts to exclude the Greek populations of Constantinople and its environs, and the Greeks of Western Asia Minor, Cappadocia and Pontos, from the Greek diaspora. For the same reason, as he points out in his overview of the historical context provided in the first chapter of his work, the Greek community of Turkey and of southern Albania should not be regarded as forming part of the Greek diaspora either: "In my view the diaspora proper is constituted by migration outwith the bounds of I Kath'imas Anatoli, the Greek East." 49 Clogg's collective volume comprises six papers dealing with the Greeks of Egypt, Australia, Canada, America, South Africa and Russia, respectively, whereas the interesting inclusion of Renée Hirschon's paper "Identity and the Greek state: some conceptual issues and paradoxes" contributes to the volume's broader problematics..$^{50}$

These two works are of utmost importance and continue to serve as an indispensable tool in the field of historiography. Lina Venturas expresses the same view, while also pointing out that: 
The contribution of the works of loannis Hassiotis and Richard Clogg to the general overview of the Greek "diasporic" phenomenon and the examination of its demographic, organisational and other aspects is indisputable. By erecting the concept of diaspora upon the aspect of common origin and presenting it as retaining the same meaning and content and describing the same realities from the 15th century to date, however they downplay, although not to the same degree, the profound political, economic and social changes as well as the heterogeneity of population groups and their cultural systems, and thus reproduce the picture of a uniform and cohesive modern Greek civilisation whose relation with Orthodoxy remained unchanged. ${ }^{51}$

Finally, it is worth stressing the role of journals at the turning point of the transition from the dictatorship to the Metapolitefsi. In addition to international journals (Diaspora: A Journal of Transnational Studies), the term diaspora would also be used in the title of a journal published by Greeks in the US, which was renamed from Journal of the Hellenic American Society ${ }^{52}$ to Journal of the Hellenic Diaspora: Critical Thought on Modern Greece. The fact that the renaming took place in September 1974 amid crucial political developments - the Turkish invasion in Cyprus, the end of the seven-year junta and the beginning of the Metapolitefsi - was all anything but random. Using an emotionally charged language and being highly critical of political developments both in Greece and in the US, Nikos Petropoulos, its editor, made the following comments on the journal's goals. It is worth mentioning that the introductory note to the journal's subsequent issue was less ideologically and emotionally charged, and devoid of any political criticism. ${ }^{53}$

The Journal's predecessor, the Journal of the Hellenic American Society, began as a resistance Journal abroad. Some might argue that the Journal should now terminate itself since the Greek junta has fallen and democracy has returned to Greece. We disagree with this euphoric analysis for several reasons and intend to continue the publication of the Journal ... We aim to establish a link between the progressive forces within Greece (now in the majority) and the progressive forces in the diaspora. The diaspora constitute about $25 \%$ of Greece's population. Some were forced to abandon their homeland because the clientelistic Greek chafiedes sold Greece to foreign interests (Western countries) who needed cheap labor for their industrialisation process and who kept the rest of the world in a state of under-development ... We, abroad, promise to reciprocate and report about the respective development in the diaspora. We hope that the Journal can become a forum for such an exchange and that it will contribute not only to our personal and social welfare but also to the progress of humanity; like other third world movements, the Greek resistance movement can contribute to the evolution of man by exposing the fascist methods of imperialists and their domestic puppets. ${ }^{54}$

\section{From 'apoikies' to 'paroikies': historical studies before the 1974 turning point}

In the early twentieth century, the first studies concerning the presence of Greeks in communities abroad emerged from within Greek communities themselves, written by authors, not all of them scholars, who were members of these communities (Trieste, Vienna). ${ }^{55}$ Within the borders of the Greek state, in February 1912, and only a few months before the outbreak of the First Balkan War, 
Spyridon Lambros, professor of history at the University of Athens, delivered his rectorial address

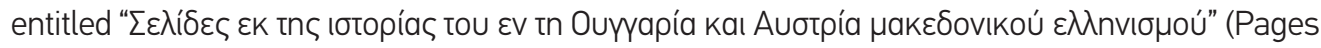
from the history of Macedonian Hellenism in Hungary and Austria), thus inciting the interest of the historiographical community in the Greek paroikies of central Europe. ${ }^{56}$ In 1919, the jurist Michail Dendias attempted to analyse the phenomenon of migration in his study "Aı ع $\lambda$ nvıкаí napoıkíaı

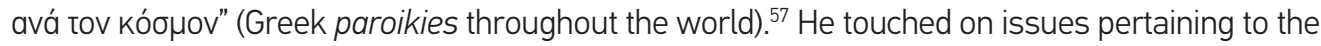
foundation of the Greek apoikies as a continuous phenomenon over the centuries, maintaining that "today's Hellenism originates from the past throughout the centuries" ${ }^{58}$ Part of his work is quite interesting as he discusses the future of migrants and the ways in which their settlement in Greece must be organised, while providing a detailed table of Greek consular authorities around the world in alphabetical order at the end of this chapter.

Prior to and after the Second World War, most studies attempting to approach the phenomenon of the Greek paroikies come from the region of Macedonia or were published there ${ }^{59}$ For in-

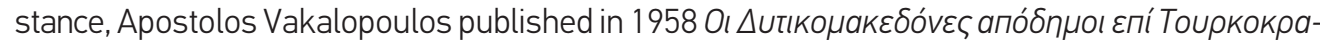
tía (Western Macedonian expatriates under Ottoman rule), focusing on the causes of migration, as well as on the economic and intellectual consequences for the homelands of migrants. ${ }^{60}$ Integrating these first studies in their historical and ideological context, Katsiardi-Hering points out that:

It was the era of the national, historicist historiography, which sought to establish an exact, "objective" and largely archival documentation. On the one hand, this period was marked by the vision of liberating the unredeemed territories and the need to bring to the fore the exploits of Greeks around the world who did not only act within the asphyxiating borders of the Greek state but mostly beyond them. On the other hand, this was a period of intense problems caused by the defensive and aggressive nationalisms of other nation-states imposing national integration policies on populations residing in their territory, thus also leading to the assimilation and shrinking of the Greek paroikies. ${ }^{61}$

In 1947, during the Greek Civil War, Nikos Polyzos published his book Essai sur l'émigration grec$q u e^{62}$ in Paris. Dedicating the largest part of his work to the post-1922 period, Polyzos linked the "migration problem" ${ }^{63}$ to the economic and social conditions prevailing in Greece and provides a detailed overview of its consequences. Polyzos placed particular emphasis on the demographic results of this phenomenon, given that: "Whether permanent or temporary, it (emigration) has an impact on workforce demographics; it affects birth rates, the quality and structure of the population in general." ${ }^{64} \mathrm{As}$ far as I can establish, Polyzos was among the first, if not the first, to have pointed out the case of Greeks coming from parts of the former Ottoman empire after 1922 who had not yet acquired the Greek citizenship, according to foreign population censuses conducted by the French National Institute of Statistics. In other words, he noted that there had been a degree of confusion among state authorities between Greek subjects of the Ottoman empire and stateless Armenians, owing to the fact that they came from the same geographical area. ${ }^{65}$

Already before and especially in the aftermath of the Second World War, the interest of historians in the origin of the institution of "communities" (KoIvotıkóৎ $\theta \varepsilon \sigma \mu o ́ \varsigma)$ during Ottoman rule ${ }^{66}$ would be reflected in most studies on "Greek communities abroad", emphasising their communal character 
and sense of continuity. ${ }^{67}$ Studies dealing with the contribution of "Greek communities abroad" to the Greek revolution would also be introduced into the scope of national historiography by the 1970s. ${ }^{68}$ Nikolaos Tomadakis, professor of Byzantine philology, delivered a speech on the occasion of the anniversary of the Greek Independence Day on 25 March 1952 at the University of Athens,

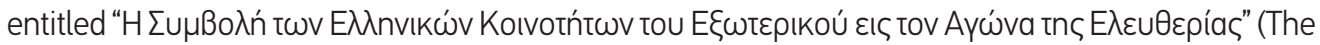
contribution of Greek communities abroad to the struggle for freedom). ${ }^{69}$

The contribution of Greeks of the diaspora as "national benefactors" was approached in much the same way, by focusing on the importance of their acts for the Greek state. ${ }^{70}$ The phenomenon of benefaction, which exceeds the scope of the present analysis, is inextricably linked to the phenomenon of migration and would be transformed over time on the basis of the preferences and social needs that it is required to cover. ${ }^{71}$ In recent years, there has been a critical approach towards the propagation of social and national stereotypes vis-à-vis the national benefactors. ${ }^{72}$ It has been argued that, for too many years, national ideology had placed benefactors among the "icons of famous saints, reflecting yet another model of 'heroism' and 'self-sacrifice". ${ }^{73}$ More precisely, in its effort to shed light on some of the hidden corners of this phenomenon (social, economic, ideological, psychological), modern Greek historiography has attempted to provide a rather concise and comprehensive image, without, however, questioning the importance and magnitude of benefaction for the Greek state. ${ }^{74}$

The founding of the Hellenic Institute for Byzantine and Post-Byzantine Studies in Venice in 1951, housed in the building of the Flanginian School of the Venetian Fraternity, would mark the proliferation of literature on the subject, illuminating the unknown aspects of the settlement of Greeks abroad. In other words, the various studies focusing on the history of Greeks under Venetian rule, the history of the fraternity and its intellectual and, mostly, publishing activities, among other things, allow for the development of new research fields in Hellenic migration studies. ${ }^{75}$

However, in order to gain a better understanding of the approaches followed by Greek historiographers until 1974, it is worth highlighting that in the first studies on the subject, "the terms apoikia/

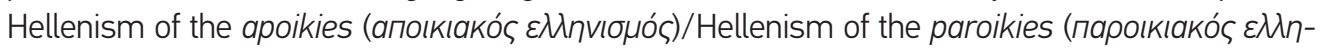

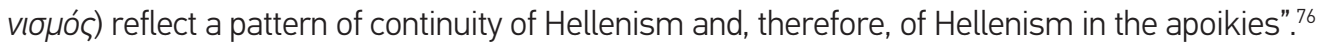
Gradually, the use of the ideologically charged term apoikia faded out and was replaced by the terms community abroad or paroikia. Meanwhile, the use of the term paroikiako phenomeno became established in various studies.

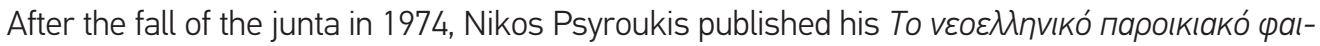
vó $\varepsilon v o$ (The modern Greek paroikiako phenomenon), attempting a first comprehensive, theoretical approach of this issue under a Marxist/anticolonial light, based on relevant literature on the subject. As noted by Christos Hadziiossif, his work "has probably contributed more than any other to the 'popularity' of the 'paroikiako phenomeno'" ${ }^{77}$ In view of the emergence of the paroikiako phenomeno as part of "the period of the so-called primary accumulation of capital", ${ }^{78}$ Psyroukis provides a concise definition of the term paroikia, as "a historically shaped community of individuals - with a common national consciousness and psyche - living outside of the national hearth and contributing with their economic and social activities to the imposition and propagation of the 
capitalist production model based on the international colonial-bourgeois division of labour" 79 The rise and fall of the paroikiako phenomeno may be divided into four historical periods: (a) its emergence, spanning from the eighteenth until the early nineteenth centuries; (b) its period of maturing and of the determination of its nature, until the late nineteenth century; (c) the period ranging from the late nineteenth century until the end of the First World War, during which it fully performs the functional role dictated by its nature; and (d) after 1918, its period of complete decadence. ${ }^{80}$ It is also interesting that, for the author, the periodisation of the paroikiako phenomeno is not identical to the one of the Greek migratory wave, as the former is related to the historical course of the Greek bourgeoisie, that is, capital, whereas the latter pertains to the evolution and development of the workforce of the Greek nation. ${ }^{81}$

\section{Historiography in the post-junta period}

The early post-junta period not only marked a systematic shift towards the study of the paroikiako phenomeno, but also a differentiation in the approach to it by entering in continuous dialogue with other disciplines and historiographical trends. The last quarter of the twentieth century constitutes an important landmark for Hellenic migration and diaspora historiography, considering that, on the one hand, emphasis was placed on social history and, on the other hand, Greek and European history began to interact, thus becoming inscribed in an international frame of reference. But, let us go back to the beginning.

First of all, it is worth noting that, already before the Metapolitefsi, the interest of researchers was no longer focused exclusively on the history of migration and the paroikies, as in previous years. The contemporary implications of this phenomenon attracted greater interest. In view of the increase in migration output in the 1960s, the National Center of Social Research, founded in 1959, carried out the first empirical studies on the topic. ${ }^{82}$ In the 1960s, most studies provided an economic analysis, examining the negative or positive impact of migration for the sending country and, in particular, for the Greek economy. ${ }^{83} \mathrm{~A}$ representative example of this trend is the work of

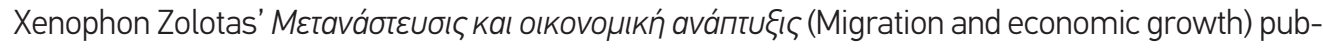
lished in 1966. ${ }^{84}$ At the same time, and especially in the post-junta period, the interest of historiographers turned to the social and psychological issues faced by migrants, both during their stay abroad and during their reintegration into Greek society and its economy, whereas issues related to second-generation migrants also began to emerge as an individual research topic. ${ }^{85}$

Let us open a short parenthesis to travel across the Atlantic to the US of the 1960s. Theodore Saloutos, a researcher of Greek origin, published in 1964 his work The Greeks in the United States, ${ }^{86}$ thus establishing the field of Hellenic-American studies. Despite the criticism it has received, his work made a decisive contribution to the field of Hellenic-American historical studies ${ }^{87}$ In the context of the domestic policy followed by the US, Saloutos' intellectual motives were shaped by the racial and ethnic issues of his time, as well as by US foreign policy towards Greece in the context of the Cold War. ${ }^{88}$ As stressed by loanna Laliotou, Saloutos "projected to the past the image of the migrant as a national model and sought to identify the aspects of migratory narratives that con- 
verged with the primary narrative of migration as a process of material benefit and intellectual and moral exaltation". ${ }^{89} \mathrm{At}$ the same time, by presenting both the absence of migrant women from the history of Greek migration and the racial discrimination against immigrants as a natural fact, "he constructed a linear and homogenising representation of Greek immigrants in the United States". 90

In the same context, though from a different angle, Helen Papanikolas' 1987 work A Greek Odyssey in the American West is also worth mentioning. ${ }^{91}$ Papanikolas' work is characterised by a constant ambiguity and conflict with the stereotypical ideals of the American history and the history of Greek migration, while Papanikolas does not share the "hegemonic narratives on the assimilation of immigrants and national homogenisation" either. ${ }^{92}$ Apart from anything else, a similar trait shared by Saloutos and Papanikolas, despite certain differences, is the deep interest they show for mi-

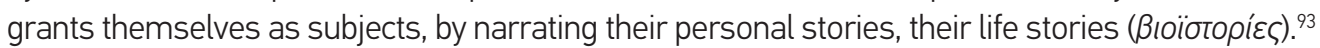
Over time, the personal life experiences of migrants, their own narrative, began to gain a special place in the field of research on Greek migration (as far as this is possible, depending on available sources and the period under study).

It was also in America where studies questioning the assimilating analysis schema of migratory groups emerged in the 1960s, arguing that these groups adapted to American society without losing their specific identity ${ }^{94} \mathrm{~A}$ third trend appeared in the 1980s, establishing a correlation between social and ethnic groups. ${ }^{95}$ Saloutos' work was continued by his student Charles Moskos. For his part, Dan Georgakas, a historian of the American labour movement, criticised the manner in which those researchers approached the history of Greeks in America, without questioning, however, their contribution to Greek American studies, highlighting, among other elements, the absence of Greek workers from their historiographical narratives. ${ }^{96}$

To return to post-junta Greece, in the 1980s, Greek historians, both in Greece and abroad, published studies dealing with the paroikiako phenomeno, thus contributing decisively to a "systematic effort to renew studies in the field". ${ }^{97}$ Indicatively, in 1980, Hadziiossif studied Greeks in Egypt from 1833 to $1856,{ }^{98}$ offering, among other things, a complete theoretical analysis of the network of Greek commercial communities of the diaspora. ${ }^{99}$ Furthermore, Olga Katsiardi-Hering's two-volume work on the Hellenic paroikia of Trieste from 1750 to 1830 was published in $1986 .{ }^{100}$ In those first studies, the Greek paroikies are analysed as part of the history of host countries and, from this perspective, their authors also discuss the degree of economic, social and political integration of migrants. ${ }^{101} \mathrm{At}$ the same time, studies dealing with the economic role of Greek communities emerged and focused on their economic rise and fall, the historic periods and reasons that led to investments in receiving countries or in Greece and, generally, the "influence of these communities in the reproduction of the model of Greece and their ambivalent role towards modernisation". ${ }^{102}$

In a critical review published in the journal O Politis in 1983, ${ }^{103}$ Hadziiossif notes that linking the study of activities in the paroikies with the evolution of the entire Greek society is a relatively recent phenomenon dating back to the 1960s. According to the author, the school of thought defending the dependent growth of the periphery in the global capitalist system, as mainly represented by Nikos Svoronos, Kostis Moskof, George Dertilis and Nikos Psyroukis, plays an important part in the study of this phenomenon. As Hadziiossif argues, the problems in understanding the paroikiako pheno- 
meno pertain to: (a) the periodisation of this phenomenon and its connection to modern European history; (b) clarifying the origin of the members of the different paroikies (for example, from mountains/islands of Greece, Cyprus); (c) determining the "influence of the paroikies on the economy of the independent Greek state", ${ }^{104}$ with special emphasis on the role of merchant shipping; and (d) the often-observed vagueness of national, linguistic and class clusters within the paroikies. From this point, the interest of Greek historiography would remain focused on those important issues.

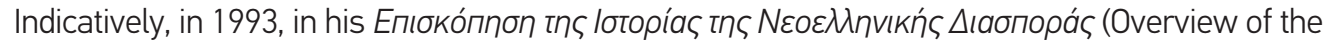
history of modern Greek diaspora), Hassiotis defines the paroikia as the settlement of Greek expatriates in urban centres abroad, forming separate social groups, regardless of their population and being distinguished from the rest of the social environment due to their common geographical and national origin. ${ }^{105}$ The incorporation of migrants from the paroikies into ethnic-religious organisational structures led to the formation of a community, without precluding the existence of several communities in the same urban centre due to a variety of political, religious, ideological, organisational and personal reasons imposing their division. ${ }^{106}$ For instance, during the First World War and the National Schism in Greece, two separate Greek clusters coexisted for a short time in Paris: the ideological and political sympathisers of the king, on the one hand, and of Venizelos, on the other. Indeed, the two clusters had different places of worship. ${ }^{107}$ In a more recent reference, Hassiotis also distinguishes the phenomenon of epoikismos in modern Greece from antiquity (due to its limited extent and significance) and from western European epoikismos (due to the non-organic link of these communities with the modern Greek state). ${ }^{108}$

At the same time, the expansion of economic history as an increasingly popular research topic in international historiography also affected the work of Greek researchers. Svoronos' work on trade in Thessaloniki, ${ }^{109}$ a publication made available to Greek readers in the post-junta period, and that of Vasilis Kremmydas on trade in the Peloponnese, ${ }^{110}$ contributed significantly in that regard. New aspects of the life of immigrants in the paroikies gradually come to light by using quantitative methods to conduct research on city archives. ${ }^{111}$ For Vaso Seirinidou, the renewal of the field of study in the 1980s consisted of two elements:

On the one hand, [in] the shift of interest from the community and community institutions, namely from the primary research field of traditional historiography on this phenomenon, to the paroikia, the broader migratory group and the various activities and experiences of its members - including the communal experience ... On the other hand, the renewal of the historiography of the paroikiako phenomeno was manifested through the relativisation of the centrality of the modern Greek state as a category for studying the paroikies. This was a critical response to the post-junta approaches, which saw the paroikies solely as an instrument for interpreting modern Greek socio-economic formation and, actually, as a factor of backwardness. Instead of being elements of the history of the Greek state, the paroikies began to be studied in terms of their own history, keeping pace with the economic and social context of the receiving space. ${ }^{112}$

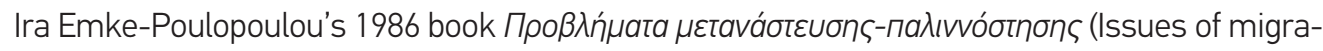
tion-repatriation) is regarded as a milestone in the analysis of the Greek migration phenomenon and an innovative work for its time. ${ }^{113}$ Approaching the demographic, economic, social and politi- 
cal aspects of migration from the nineteenth century to the 1980s, she provides a comprehensive analysis of this phenomenon, by integrating her problematics into the international theoretical debates of the time. Particular emphasis is placed on the consequences of apodimia and repatriation in sectors like employment, agricultural production, consumption, inflation, vocational training and education, while the author investigates the consequences of remittance inflows and outflows in different periods, throughout a large part of her work. The interdisciplinary approach to the diaspora-migration phenomenon is now common ground, comprising findings from social anthropology, sociology, geography, economics, and demography. In this context, her innovative approach follows the new trends developed in international research around migration.

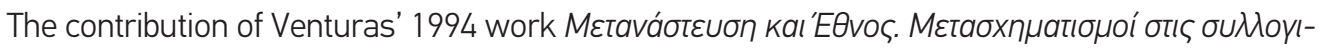

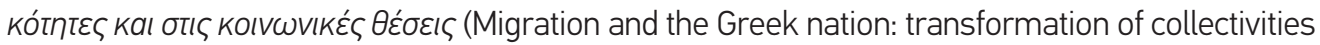
and social positions), ${ }^{114}$ has been quite significant for Greek historiography as it was one of the first attempts to approach migration theoretically. Published amid a decade of international political and social turmoil, Venturas' book stresses the need to redefine the conceptual tools and analysis methods of issues pertaining to collective identity formation and otherness. ${ }^{115}$ She inscribes the analysis of the migration phenomenon in the context of modern theoretical approaches and schools of thought in Europe and the US, while, by focusing on the case of postwar economic emigration to western Europe, she raises new questions, including the role of migratory networks and the second generation issue. In addition, she opens the debate on the relationship between nation and foreigner by discussing the assimilation factors of migrant ethnic groups and the ways in which their identity is formed. The indicative list of foreign literature references on issues of migration, nationalism and racism in the book is equally interesting. In other words, Venturas' case clearly demonstrates that many Greek historians interact with their colleagues abroad and keep informed of international historiographical trends. The history of Greek migration walks hand-inhand with international concerns and is an integral part of it.

The contact of Greek historians with the Annales School ${ }^{116}$ has contributed significantly to the historiographical shift of the post-junta period. In parallel, interaction with other disciplines has yielded significant benefits and new theoretical and methodological tools have come to the fore in contemporary research. Historical demography, sociology, geography, urban history, family history, anthropology, history of mentalities, microhistory, business history and theories of identity and nationalism are only some of the new fields that have had a catalytic influence on the renewal of migration studies and the removal of "dogmatically rigid schemas". ${ }^{117}$ At the same time, the business activities of the Greek diaspora incited the interest of many researchers, who would use previously untapped archival material (business records, family records, commercial correspondence) emphasising family and business networks. ${ }^{118}$

Nonetheless, apart from the increasing number of studies concerning the Greek paroikies, the 1980 s and 1990s were characterised by the emergence of studies (though significantly less in number) on the historical aspects of postwar emigration to western Europe. ${ }^{119}$ Thus, researchers attempted to examine relatively recent parts of Greek history, such as labour migration, in order to reveal the causes and the social, political and, especially, economic conditions prevailing in the sending country. New elements emerged in respect of postwar migration flows given that "emigra- 
tion to Western Europe from 1945 to 1974, much more than movements to other continents and in other periods, was governed by an organised labour import policy adopted by host countries, which was introduced by the state and employers". ${ }^{120}$ The organised and coordinated workforce emigration is not an exclusive phenomenon of the postwar years. Though there have been no formal bilateral agreements, during the First World War and due to the increased needs of French industry, French public authorities organised the emigration of workers from areas of the Greek state and the Dodecanese from 1916 to $1918 .{ }^{121}$ This was actually the first organised migration flow of Greek workers, ${ }^{122}$ long before the emigration movements of the 1950s and 1960s. Nevertheless, the fact that postwar emigration to western Europe was largely governed by bilateral agreements and was, at least theoretically, of "temporary" character, transformed existing migration conditions and, subsequently, brought changes to the study of this phenomenon.

The development of the latest historiographical methods, coupled with the dissemination of oral history ${ }^{123}$ in Greece, turned the spotlight on many surviving protagonists of postwar migration. The "voice of the past"124 begin to take a prominent position in the nascent Greek migration studies. For instance, the 30 interviews conducted by Venturas provide us with evidence on the everyday life and the settlement conditions of Greek workers in Belgium. ${ }^{125} \mathrm{At}$ the same time, the oral testimonies of Greeks from the Netherlands allow us to approach a particularly sensitive issue, that of psychosomatic disorders, ${ }^{126}$ thereby opening a debate around the relationship between migration and the human body. ${ }^{127}$ Similarly, Maria Damilakou's study on Greek merchants/confectioners in Buenos Aires (most of whom had settled in Argentina in the interwar years) was largely based on personal interviews conducted by the author in the late 1990s, as well as on older interviews published in the newspaper of the confectionery wholesalers union. Thus, by means of oral interviews, the author sought to highlight the significance of relationships and the role of informal social networks in shaping the labour market and determining the potential of social ascendancy in the case of Greek merchants. ${ }^{128}$

In the case of the Greeks in Belgium, oral testimonies also allowed researchers to reveal, to a greater extent, the variety of behaviours that eventually developed within a socially and economically homogeneous (at least initially) Greek paroikia. ${ }^{129}$ In her paper, which was included in a collective volume dedicated to "Paris of the foreigners" in 1989, and in the context of her research on the case of Jews, Nancy Green stresses the importance of studying the particular characteristics and personal routes existing within the ethnic group itself, thus leading to the "deshomogenisation" (déhomogénéisation) of the group and making its diversity more visible. ${ }^{130}$ Geographical and social mobility within the migratory group itself may thus become more apparent and contribute to a better analysis of the way the group integrates and/or assimilates in the host country. In the case of Greek populations, though, some researchers tend to regard migratory groups as homogeneous, while others have already started to stress that "the fact that migration communities are not uniform, that a social hierarchy is developing within them and [the fact] that parts of them are in conflict in order to obtain political and ideological dominance is being disregarded". $1{ }^{131}$ In the same context, towards the end of the twentieth century, Greek historiographers had already begun to discuss the factors contributing to the formation of an ethnic identity. Ethnic identity is being reconstructed through the interaction of both social and cultural elements in the host country and through the relationships developed between local and foreign populations. In other words, this is 
not a static object which is transferred from the host country and remains intact over time, but a living element, in constant mutation and redefinition. ${ }^{132}$

This survey of Greek migration historiography in the twentieth century cannot fail to mention the impact of the changes on the international scene since 1989, especially in Eastern Europe and the former Soviet republics. Although postwar repatriations from the Soviet Union had already started in the late 1970s and the early 1980s, they gained massive dimensions in the 1990s due to the degeneration of the Soviet political-economic system and the establishment of the Commonwealth of Independent States (CIS). ${ }^{133}$ In this context, the repatriation programmes addressed to Greek populations residing in these countries, combined with the establishment of the World Council for Hellenism Abroad (SAE) in Thessaloniki in 1993, attracted the interest of some Greek researchers to those issues..$^{134}$ This new institution was more ideologically and politically charged than the General Secretariat of Expatriate Greeks, founded in 1983. There was a proliferation of literature dealing with the history of Greeks in Russia, Transcaucasia and the Soviet Union overall, ${ }^{135}$ while special emphasis was placed on the case of Greeks from Pontos (often connected to promoting the request for the recognition of the genocide). ${ }^{136}$ Accordingly, researchers also focused on issues related to the Greek communities of the Balkans. ${ }^{137}$

\section{Final remarks: towards the dawn of the 21 st century}

A large number of books, papers, PhD theses and studies, some of which had been started in the previous decade, were published in the first years of the twenty-first century, thus further enriching Greek historiography and introducing new topics and research tools..$^{138}$ In addition, there has been a shift in the research focus: while most studies emerging in the 1980s and at least until 2000 focused on the history of settlements of the Greek maritime trade network (Alexandria, Trieste, Odessa, Marseille, Livorno, London), the history of the paroikies of central Europe, which, as we have seen, was a principal field of research until the 1960s, remained largely unexplored. ${ }^{139}$ The interest of researchers in the matter was only renewed in the early part of this century. They now had access to archival material that had been inaccessible for many years. ${ }^{140}$

At the same time, there has been a systematic turn towards studying the national policies adopted by Greece, as a sending country, vis-à-vis its expatriate citizens and their progeny over time: this is a research field that remains very fertile given that many of its aspects have not been adequately explored yet. Indeed, as far as we know, Greek literature on the subject is still quite limited. This problematic focuses not only on the ways in which Greece treated its citizens outside the Greek borders but also on the conditions prevailing inside the country, which imposed the adoption of specific policies at certain times. ${ }^{141}$ In other words, new studies have emerged that focus on the policies of the Greek state towards the omogeneia at different historical periods, analysing the reasons why such policies were adopted, the factors affecting and reshaping them as well as the objectives pursued from time to time. ${ }^{142}$ 
Finally, the integration of comparative history in migration studies has redefined the analytical methods used to approach this phenomenon, despite the fact that the international literature has long dealt with such issues. In 2002, in her study Repenser les migrations, Green identifies three comparative models of migration conditions that allows for the establishment of a dialectic relationship between the ecumenical and the particular: (a) the linear model, which involves a comparison between before and after, between the sending and the host country; (b) the convergent model, which focuses on a specific migration ethnicity in one space compared to other ethnicities residing in the same space; and (c) the divergent model, under which the migratory group itself is being studied in different spaces. ${ }^{143}$ Greek historiographical research on these issues has also been quite limited.

However, apart from comparison itself (which requires the existence of specific conditions), ${ }^{144}$ Greeks had already become an object of study in the previous decades regarding their coexistence with other ethnic groups in host countries. ${ }^{145}$ This facilitates our understanding of the various processes occurring in their place of settlement, the policies adopted by host countries and their interaction with other migration groups, so as to acquire a more complete and comprehensive view of the Greek presence abroad. In addition, this helps us answer any questions that may arise during our research. For instance, it is only possible to understand the legal status and the general way of assimilating migrants from Asia Minor fleeing directly to France after 1922 by studying the legal status of the host country itself and the situation prevailing in respect of other refugees (Italian and Spanish, but not Armenian, as they are a special case) who had settled there in the same period.

This survey has attempted to offer an account of Greek historiographical works on diaspora and migration and contribute to the assessment of them. Today, Greek historiography is very rich and touches on more and more aspects of the history of Greek migration and diaspora over time. In addition, it tends to provide a critical view of international approaches to the subject. ${ }^{146}$ However, as mentioned earlier, the research on migration and diaspora studies is an interdisciplinary field, but the overall analysis of it lies beyond the scope of this work. In the case of Greece, the interdisciplinary approach towards this phenomenon is also reflected in the new research trends that are gradually gaining ground. There has been a more systematic shift from the exclusive study of emigrants to that of immigrants. Historical, sociological, social anthropological, economical, urban and gender studies revolving around issues of settlement, urban transformations, integration, assimilation and coexistence with local populations are becoming more prominent. ${ }^{147}$ The history of foreigners in Greece has become a separate research topic holding its own position in the Greek historiography of the twenty-first century.

\section{NOTES}

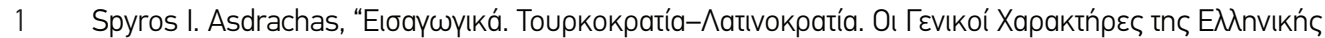
Iotopías, 1453-1770 [Introduction. Turkocracy-Latinocracy. General characteristics of Greek history,

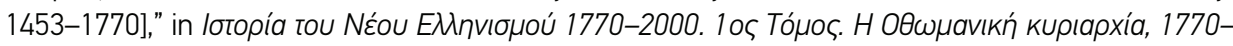

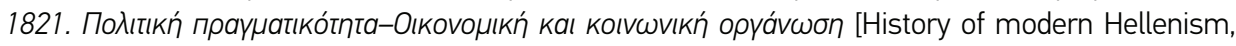
1770-2000. Vol. 1, Ottoman rule, 1770-1821. Political reality - economic and social organisation], ed. Vasilis Panagiotopoulos (Athens: Ellinika Grammata, 2003), 38. 
2 For a brief albeit comprehensive history of the Greek diaspora in that period, see Olga Katsiardi-Her-

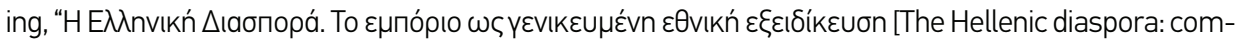

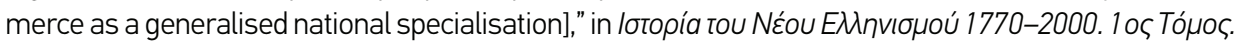

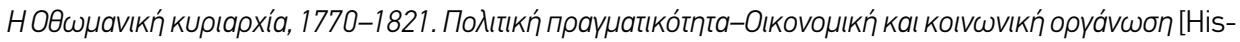
tory of modern Hellenism, 1770-2000. Vol. 1, Ottoman rule, 1770-1821. Political reality - economic and social organisation], ed. Vasilis Panagiotopoulos (Athens: Ellinika Grammata, 2003), 87-112.

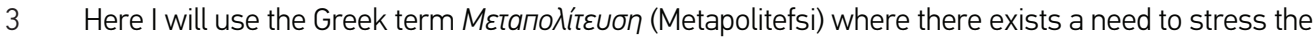
turning point of 1974 and the period starting with the fall of the dictatorship and the restoration of democracy.

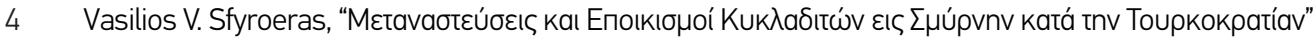
[Migrations and colonies of populations from the Cyclades in Smyrna during Ottoman rule], Mikrasiati-

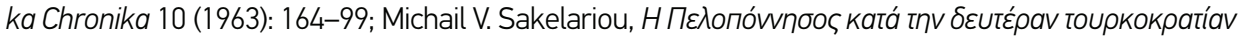
(1715-1821) [The Peloponnese during the second period of Ottoman rule, 1715-1821], 2nd ed. (Athens:

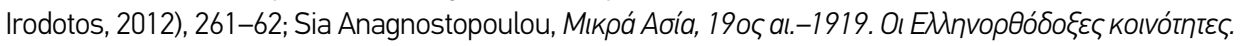

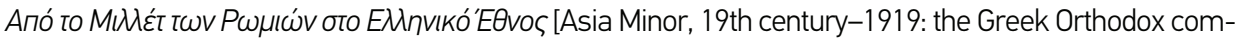
munities: from the Rum millet to the Greek nation], 2nd ed. (Athens: Ellinika Grammata, 1998), 189-238.

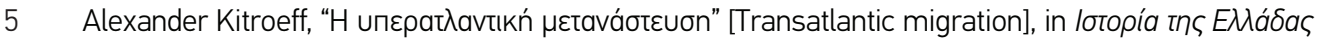

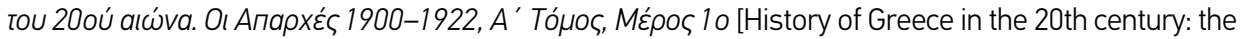
origins, 1900-1922, vol. 1, part 1], ed. Christos Hadziiossif (Athens: Vivliorama, 1999), 124.

Ibid., 125; Socrates D. Petmezas, "Diverse responses to agricultural income crisis in a southeastern European economy: transatlantic emigration from Greece (1894-1924)," in Fra spazio e tempo. Studi in onore di Luigi de Rosa III, ed. Ilaria Zilli (Napoli: Edizioni Scientifiche Italiane, 1995), 425-87.

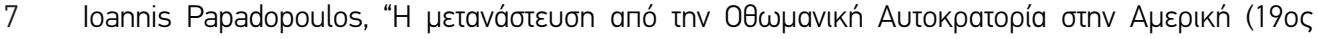

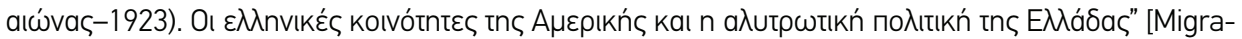
tion from the Ottoman empire to America, 19th century-1923: the Greek communities of America and the irredentist policy of Greece] (PhD diss., Panteion University of Social and Political Sciences, 2008), $30-46$.

8 Charles Moskos, "The Greeks in the United States," in The Greek diaspora in the twentieth century, ed. Richard Clogg (London: Macmillan, 1999), 104-5.

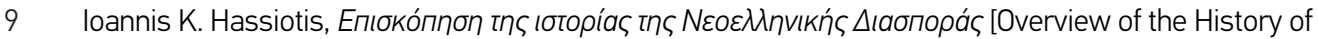
the modern Greek diaspora] (Thessaloniki: Vanias, 1993), 120.

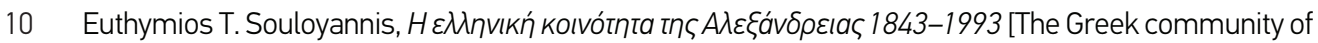
Alexandria 1843-1993] (Athens: ELIA, 1994).

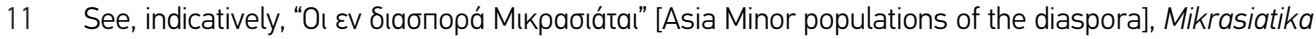

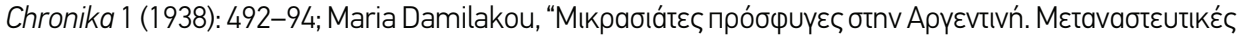

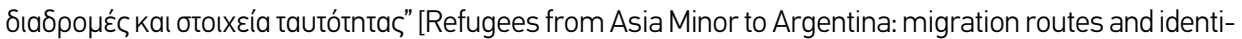
ty elements], Ta Istorika 42 (2005): 177-202; Eleni Korma, "Les réfugiés grecs d’Asie Mineure en France entre émigration politique et immigration économique, 1916-1939" (PhD diss., Université Paris IPanthéon Sorbonne, 2009).

12 Paschalis M. Kitromilides and Alexis Alexandris, "Ethnic survival, nationalism and forced migration: the historical demography of the Greek community of Asia Minor at the close of the Ottoman era," Bulletin of the Centre for Asia Minor Studies 5 (1984-1985): 34.

13 Marie-Eve Théodoridès, "Les immigrés grecs d'Asie Mineure et leur idéologie nationale" (PhD diss., Université de Paris VII, 1980). 


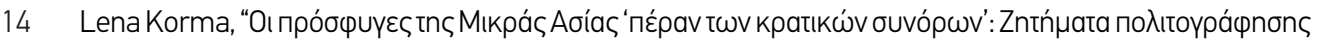

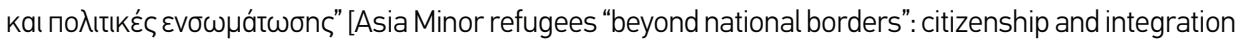

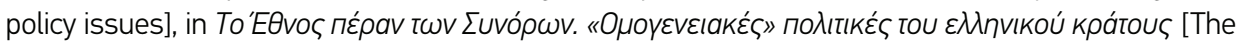
nation beyond borders: policies of the Greek state for the "Omogeneia"], ed. Lina Venturas and Lambros Baltsiotis (Athens: Vivliorama, 2013), 171-92.

15 Apostolos Karpozilos, "The Greeks in Russia," in The Greek diaspora in the twentieth century, ed. Rich-

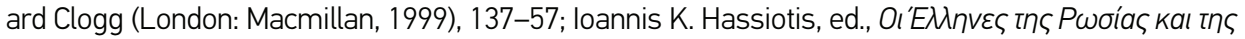

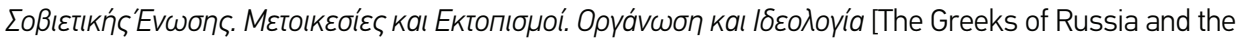
Soviet Union: relocations and displacements; organisation and ideology] (Thessaloniki: University Studio Press, 1997).

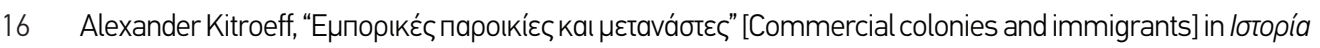

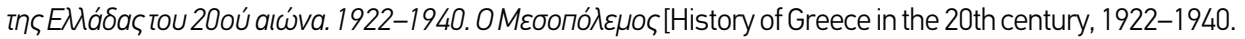
The interwar period], vol. 2, part 1, ed. Christos Hadziiossif (Athens: Vivliorama, 2003), 365.

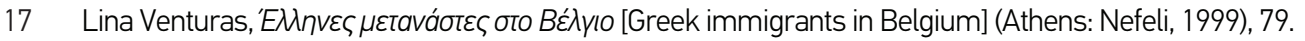

18 See, indicatively, Vyron Kotzamanis, "Le mouvement migratoire dans la Grèce de l'après-guerre. Antécédants migratoires, mécanismes 'liberateurs' et conditions permissives au départ durant les années cinquante/soixante-dix" (PhD diss., Université Paris X, 1987); Anastassios M. Tamis, The Greeks

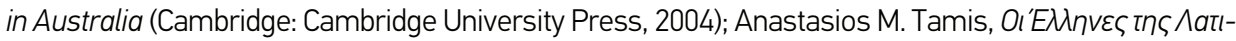

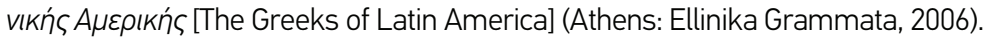

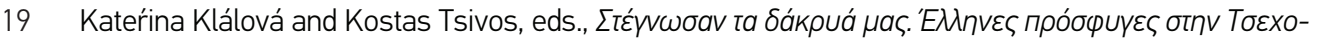
б入оßакі́a [Our tears have gone dry: Greek immigrants in Czechoslovakia] (Athens: Alexandria, 2015); Eftychia Voutura, Vasilis Dalkavoukis, Nikos Marantzidis and Maria Bontila, eds., То óпৗо парá пóбa.

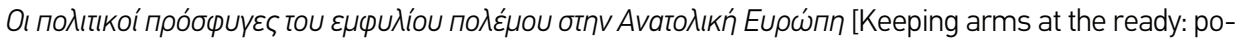
litical refugees of the civil war in Eastern Europe] (Thessaloniki: University of Macedonia Press, 2005);

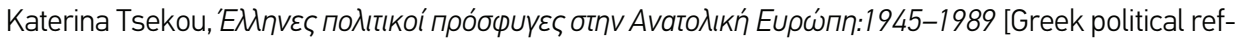
ugees in eastern Europe, 1945-1989] (Athens: Alexandria, 2013); Vasiliki Kilekli, "Les Grecs en France pendant la junte des colonels (1967-1974): émigration politique et lutte contre la dictature" (PhD diss., Université de Paris I-Panthéon Sorbonne, 2012).

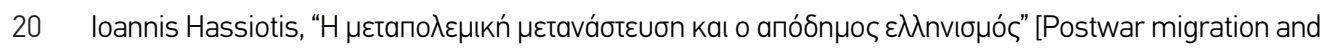
expatriate Hellenism], in lotopía tou EMnvikoú'EOvous, vol. 16 [History of the Greek nation] (Athens: Ek-

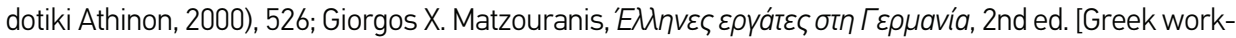
ers in Germany] (Athens: Gutenberg, 1974).

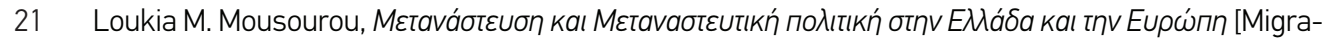
tion and migration policy in Greece and in Europe] (Athens: Gutenberg, 1991), 48.

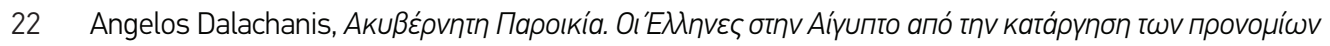

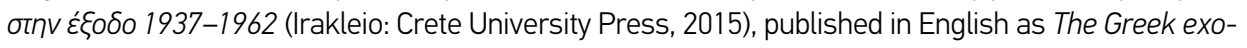
dus from Egypt: diaspora politics and emigration, 1937-1962 (New York: Berghahn, 2017).

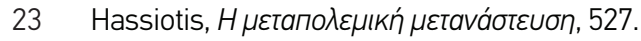

24 Ibid., 534.

25 Given that no distinction is made in English between the Greek terms пароıкіa (paroikia) and апоıі́ (ароіkia), as they both translate into "colony", we will use the terms in Greek in order to stress the differentiation of their meaning as expressed in the approaches of twentieth-century Greek historiography.

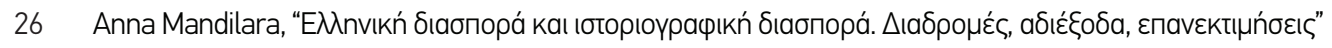
[Greek diaspora and historiographical diaspora: routes, dead ends, re-evaluations], Mnimon 22 (2000): 241. 
27 The following literature is indicative of the Greek case: Dimitri. C. Constas and Athanassios G. Platias, eds., Diasporas in world politics: the Greeks in comparative perspective (London: Palgrave Macmillan, 1993); Michel Bruneau, ed., Diasporas (Montpellier: Reclus, 1995); Georges Prevelakis, ed., Les Réseaux des Diasporas/The networks of diaspora (Paris: L'Harmattan, 1996); Minna Rozen, ed., Homelands and diasporas: Greeks, Jews and their migrations (London: IB Tauris, 2008); Dimitris Tziovas, ed., Greek diaspora and migration since 1700: society, politics and culture (Farnham: Ashgate, 2013).

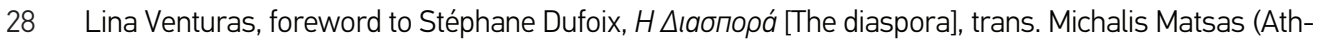
ens: Nisos, 2010), 14.

29 Stéphane Dufoix, Diasporas, trans. William Rodarmor (Berkeley: University of California Press, 2008), 4.

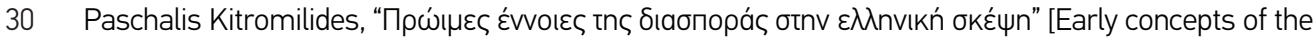

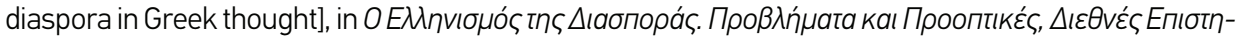

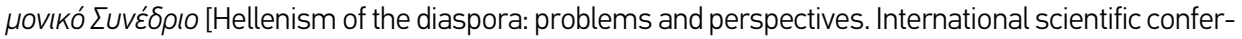
ence] (Athens: A.A. Livanis, 1998), 215.

31 Chantal Bordes-Benayoun and Dominique Schnapper, Diasporas et Nations (Paris: Odile Jacob, 2006), 11.

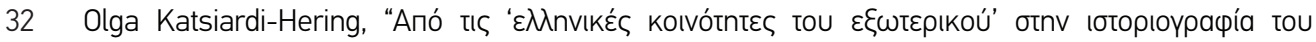

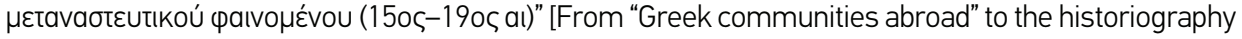

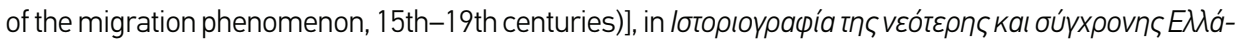
Sas 1833-2002 [Historiography of modern Greece, 1833-2002], vol. 2, ed. Paschalis M. Kitromilides and Triantafyllos E. Sklavenitis (Athens: Department of Neohellenic Research/National Hellenic Research Foundation, 2004), 226. Author's emphasis.

33 Michel Bruneau, "Comment définir la diaspora grecque?," in Arméniens et Grecs en diaspora: approches comparative, ed. Michel Bruneau, loannis Hassiotis, Martine Hovanessian and Claire Mouradian (Athens: École française d'Athènes, 2007), 19.

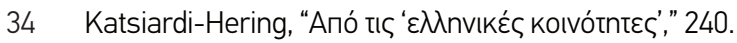

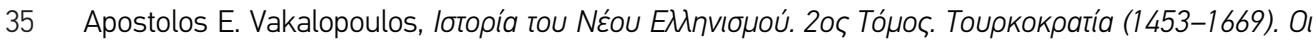

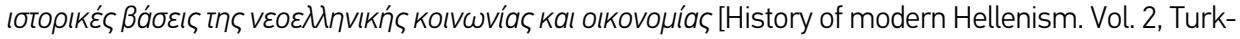
ish rule, 1453-1669: the historical foundations of modern Greek society and economy], 4th ed. (Athens: Irodotos, 2008), 466-82.

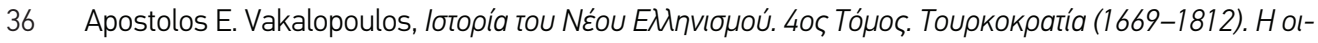

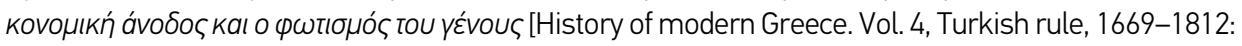
the economic rise and the nation's enlightenment] (Athens: Irodotos, 2009), 444-64.

37 Ibid., 103-12.

38 Ibid., 236-88.

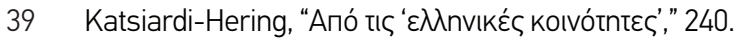

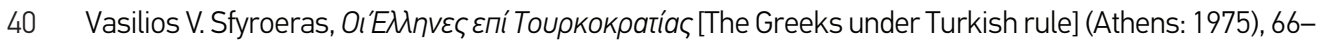
79.

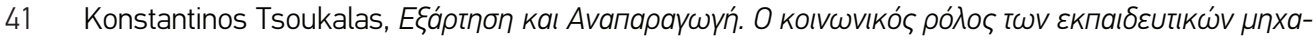

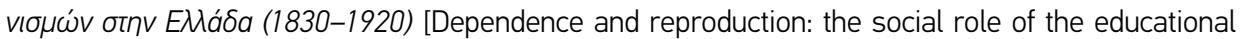
mechanisms in Greece, 1830-1920], trans. Ioanna Petropoulou and Konstantinos Tsoukalas (Athens: Themelio, 1977), 288-95, 303-13.

42 Antonis Liakos, "Modern Greek historiography (1974-2000): the era of tradition from dictatorship to de- 
mocracy," in (Re)Writing history: historiography in southeast Europe after socialism, ed. Ulf Brunbauer (Münster: LIT, 2004), 19.

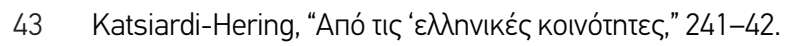

44 Michail Sakellariou, "La typologie de la diaspora grecque," in Proceedings of the first international congress on the Hellenic diaspora from antiquity to modern time, ed. John M. Fossey (Amsterdam: Gieben, 1991), 15.

45 John M. Fossey, "Introduction," in Proceedings of the first international congress on the Hellenic diaspora from antiquity to modern time, ed. John M. Fossey (Amsterdam: Gieben, 1991), xiii-xiv.

46 Hassiotis, Eпıбкónпбп, 19.

47 Ibid., 23.

48 Richard Clogg, "Introduction," in The Greek diaspora in the twentieth century, ed. Richard Clogg (London: Macmillan, 1999), 7.

49 Ibid., 8. Author's emphasis.

50 Renée Hirschon, "Identity and the Greek State: Some Conceptual Issues and Paradoxes," in The Greek diaspora in the twentieth century, ed. Richard Clogg (London: Macmillan, 1999), 158-80.

51 Lina Venturas, "Divergent Routes to the Study of the Diaspora in Postwar Greece and the USA," Journal of the Hellenic Diaspora 30/1 (2004): 126-27.

52 Three issues were published under this title: in 1973 and in Jan. and Apr. 1974.

53 Nikos Petropoulos, "The Journal of the Hellenic Diaspora: Critical Thought on Modern Greece: Politics and Prospects," Journal of the Hellenic Diaspora: Critical Thought on Modern Greece 4 (1974): 1-8; Nikos Petropoulos, "Note to contributors," Journal of the Hellenic Diaspora: Critical Thought on Modern Greece 1 (1975): 1-4.

54 Petropoulos, "The Journal of the Hellenic Diaspora," 1, 4. Emphasis in the original. Author's emphasis.

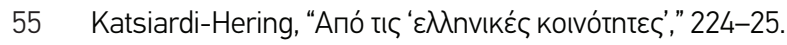

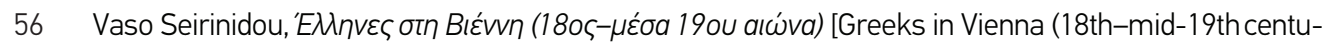
ries)] (Athens: Irodotos, 2011), 21.

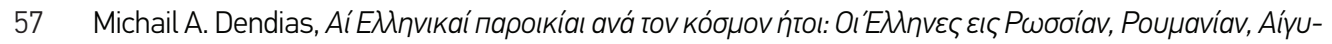

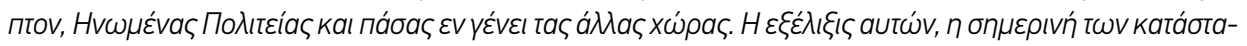

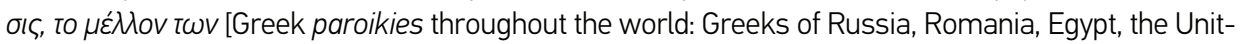
ed States and all other countries. Their development, current situation and future conditions] (Athens: Sideris), 1919.

58 Ibid., 13.

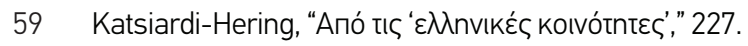

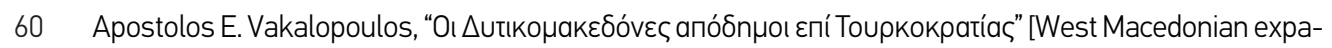

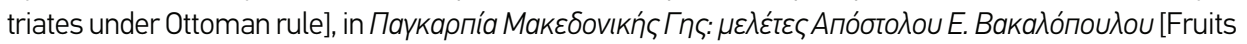
of the Macedonian earth: studies by Apostolos E. Vakalopoulos (Thessaloniki: Society for Macedonian Studies, 1980), 403-47.

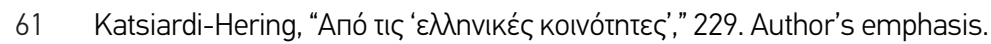

62 Nicos J. Polyzos, Essai sur l'émigration grecque. Étude Démographique, Économique et Sociale (Paris: Recueil Sirey, 1947). 
64 Ibid., 197.

65 Ibid., 80.

66 For a brief criticism of the origins and organisation of the institution of "community" during Ottoman

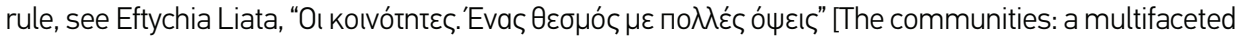

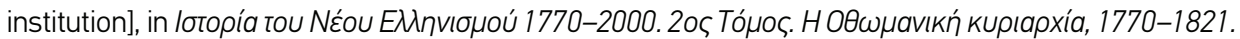

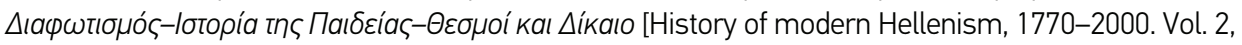
Ottoman rule, 1770-1821: enlightenment, history of education, institutions and law], ed. Vasilis Panagiotopoulos (Athens: Ellinika Grammata, 2003), 309-24.

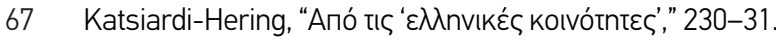

$68 \quad$ Ibid., 232.

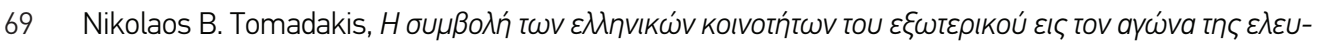
Acpias [The contribution of Greek communities abroad to the struggle for freedom] (Athens: Minas Myrtidis, 1953).

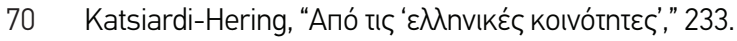

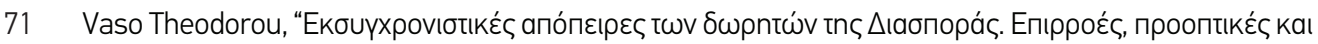

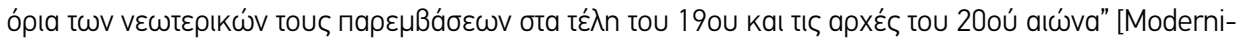
sation attempts of benefactors from the diaspora: the influence, perspectives and limits of their mod-

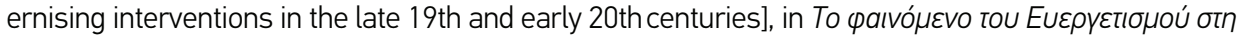

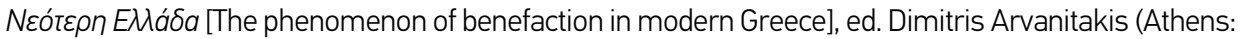
Benaki Museum, 2006), 62.

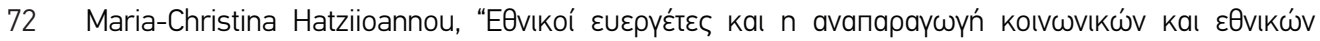

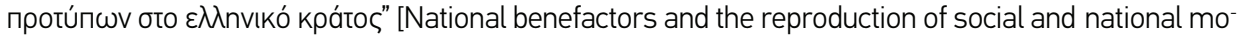

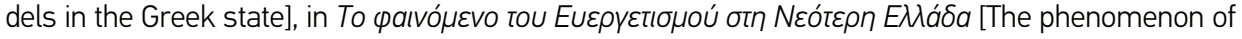
benefaction in modern Greece], ed. Dimitris Arvanitakis (Athens: Benaki Museum, 2006), 31-45.

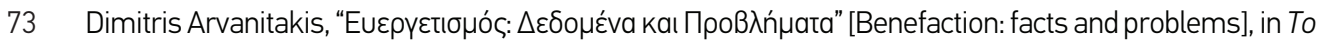

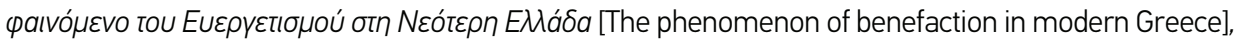
ed. Dimitris Arvanitakis (Athens: Benaki Museum, 2006), 14.

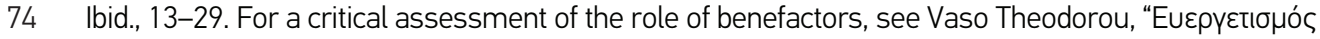

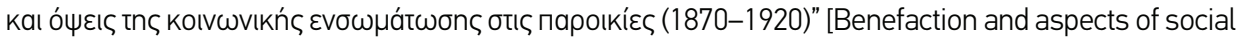
integration in the paroikies, 1870-1920)], Ta Istorika 7 (1987): 119-54.

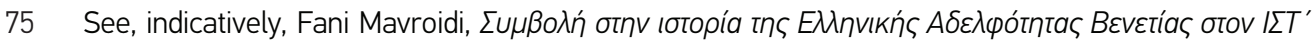

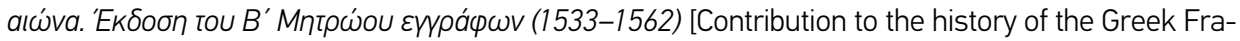
ternity in Venice in the 16th century: Publication of the 2 nd registry of documents, 1533-1562] (Athens:

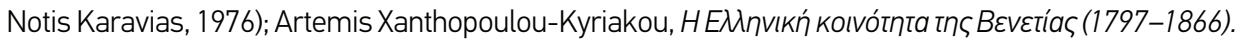

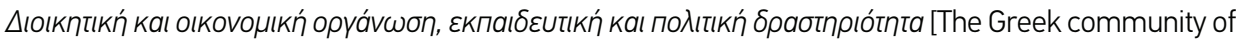
Venice, 1797-1866: administrative and financial organisation, educational and political activity] Thes-

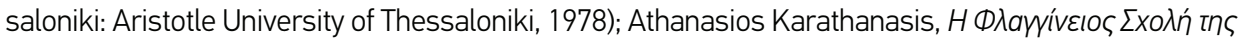
Bevetías [The Flanginian School of Venice] (Thessaloniki: Kyriakidis Bros, 1986). For a brief albeit concise reference to the institute's publishing work and the issues approached, please refer to: Katsiar-

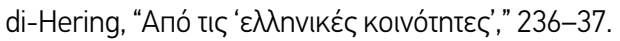

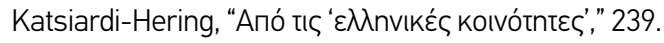




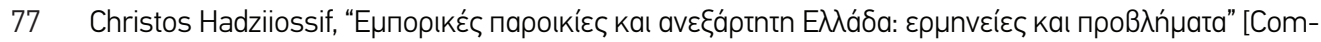
mercial paroikies and independent Greece: interpretations and problems], O Politis 62 (1983): 30.

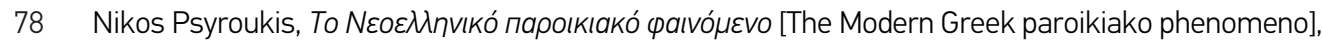
4th ed. (Athens: Epikerotita, 1977), 26.

79 Ibid., 2

80 Ibid., 31-35.

81 Ibid., 33.

82 The Athens Institute of Social Sciences (KKEA) operated until 1967 and was refounded as the Nation-

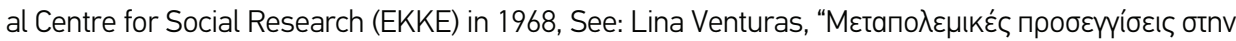

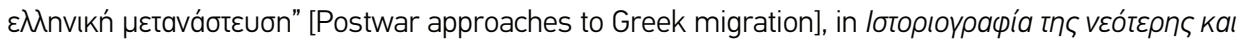

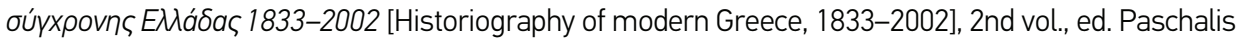
M. Kitromilides and Triantafyllos E. Sklavenitis (Athens: Department of Neohellenic Research/National Hellenic Research Foundation, 2004), 253, which provides a comprehensive bibliography of KKEA and EKKE publications until the fall of the Greek dictatorship.

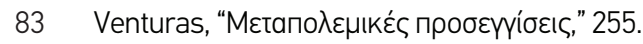

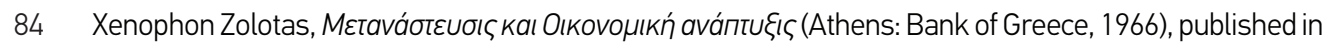
English as International Labor Migration and Economic Development, with Special Reference to Greece (Athens: Bank of Greece, 1966).

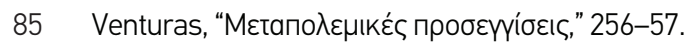

86 Theodore Saloutos, The Greeks in the United States (Cambridge: Harvard University Press, 1964).

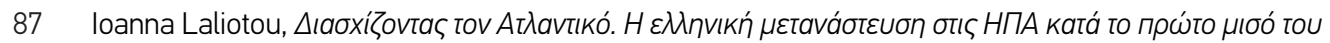

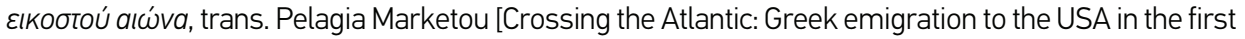
half of the 20th century] (Athens: Polis, 2006), 351. Published in English as Transatlantic Subjects. Acts of Migration and Cultures of Transnationalism between Greece and America (Chicago: University of Chicago Press, 2004).

88 Ibid., 352-53.

89 Ibid., 358.

90 Ibid., 359

91 Helen Papanikolas, A Greek odyssey in the American west (Lincoln: University of Nebraska Press, 1987).

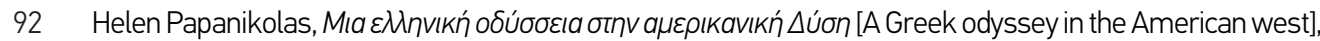
foreword by loanna Laliotou, trans. Michalis Makropoulos (Athens: Estia, 2005), 18-19, 21. For a critical review of Papanikolas' work on the occasion of the publication of the Greek version, see Margarita Dounia, "A Greek odyssey in the American west," Historein 8 (2008): 199-201, http://dx.doi.org/10.12681/historein.45.

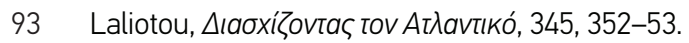

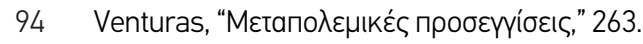

95 Ibid., 264.

96 Ibid., 264-65.

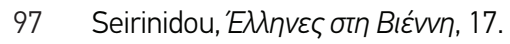

98 Christos Hadziiossif, “La colonie grecque en Égypte (1833-1856)" (PhD diss., Université de Paris IVÉcole Pratique des Hautes Études, 1980). 


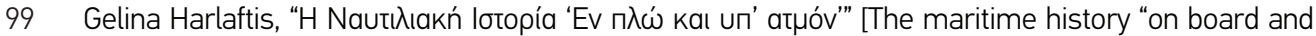

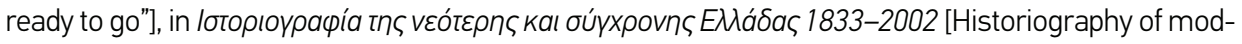
ern Greece, 1833-2002], 2nd ed., ed. Paschalis M. Kitromilides and Triantafyllos E. Sklavenitis (Athens: Department of Neohellenic Research/National Hellenic Research Foundation, 2004), 432.

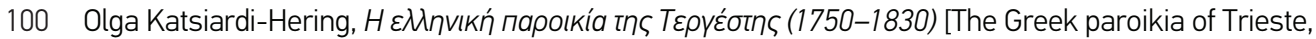
1750-1830] (Athens: National and Kapodistrian University of Athens, 1986).

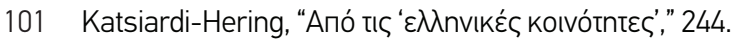

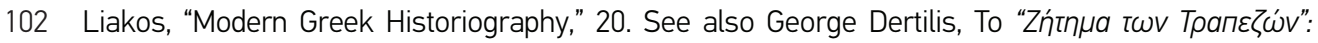

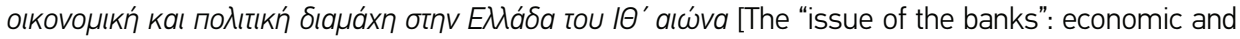

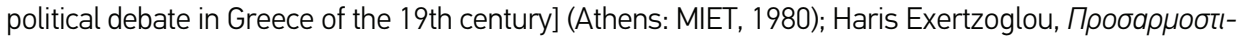

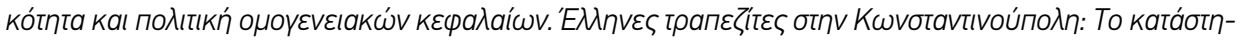

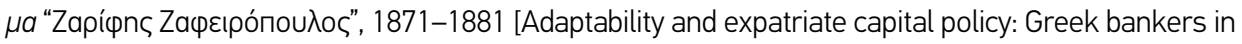
Constantinople: the "Zarifis Zafiropoulos" store, 1871-1881] (Athens: Foundation for Research and Education, Commercial Bank of Greece, 1989).

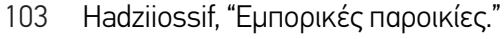

104 Ibid., 33.

105 Hassiotis, Eпıбкónпбп, 19.

106 Ibid., 20.

107 Despoina Papadopoulou, "Les Grecs à Paris à la fin du XIXe siècle. La construction d'une communauté migrante" (PhD diss., EHESS, 2004), 185; Korma, “Les réfugiés grecs," 289-96.

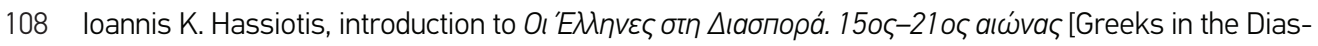
pora, 15th-21st century], ed. Ioannis K. Hassiotis, Olga Katsiardi-Hering and Evridiki A. Abatzi (Athens: Hellenic Parliament, 2006), 17. Author's emphasis.

109 Nicolas Svoronos, Le Commerce de Salonique au XVIII siècle (Paris: PUF, 1956).

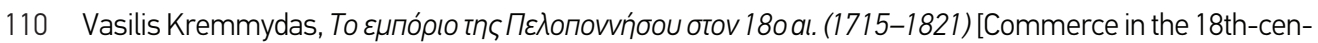
tury Peloponnese] (Athens, 1972).

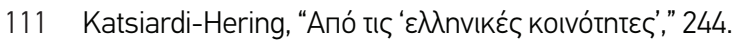

112 Seirinidou, 'EMnves otn BlÉvvn, 17-19. My emphasis.

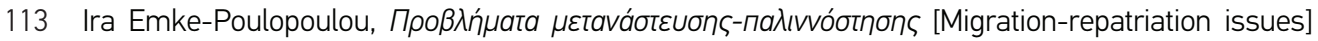
(Athens: Institute for the Study of the Greek Economy/Society for Journalistic Studies, 1986).

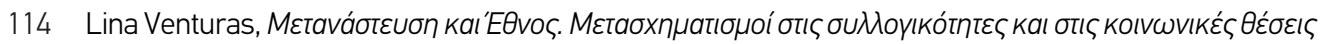
[Migration and the Greek nation: transformation of collectivities and social positions] (Athens: Society for Neohellenic Studies/Mnimon, 1994).

115 Ibid., 7.

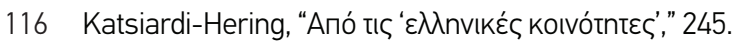

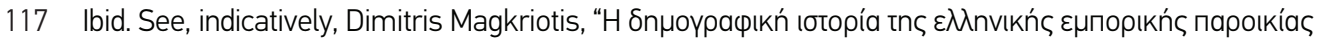

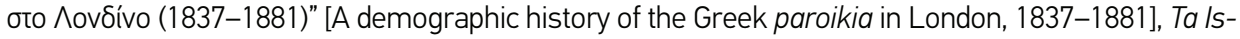
torika 3 (1986): 349-368; Alexander Kitroeff, The Greeks in Egypt, 1919-1937: ethnicity and class (London: Ithaca, 1989); Olivier Deslondes, Les fourreurs de Kastorià entre la Macédoine et l'Occident (Paris: CNRS Éditions, 1997); Anna Mandilara, “The Greek business community in Marseilles, 1816-1900: in- 
dividual and network strategies" (PhD diss., European University Institute, 1998); Vasilis Kardassis, 'EX-

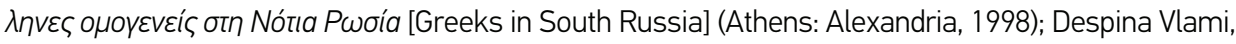

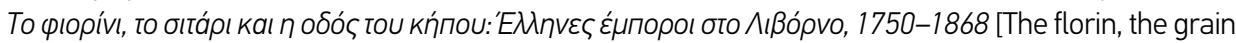
and the garden street: Greek merchants in Livorno, 1750-1868] (Athens: Themelio, 2000).

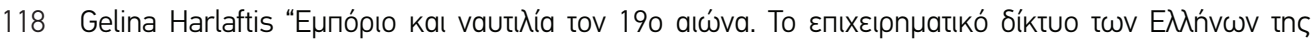

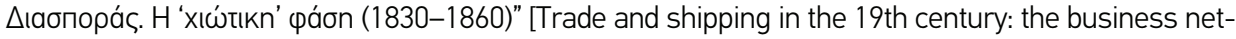
work of the Greek diaspora; the "Chian" phase, 1830-1860], Mnimon 15 (1993): 69-127; Gelina Harlaftis, A history of Greek-owned shipping: the making of an international tramp fleet in the nineteenth and twentieth centuries (London: Routledge, 1996); loanna Pepelasis-Minoglou and Helen Louri, "Diaspora entrepreneurial networks in the Black Sea and Greece, 1870-1917," The Journal of European Economic

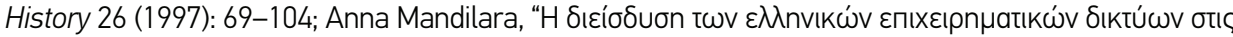

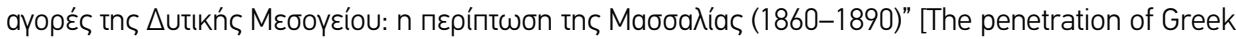
business networks in the markets of the western Mediterranean: the case of Marseille, 1860-1890], Ta Istorika 33 (2000): 253-70.

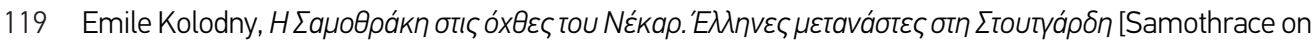
the banks of the Neckar: Greek immigrants in Stuttgart] (Athens: National Centre of Social Research, 1985); Giorgos X. Matzouranis, Ta пaıઠı́a tou Nótou [Children of the south] (Athens: Gutenberg, 1990);

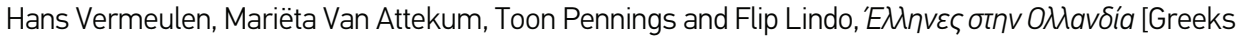

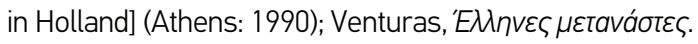

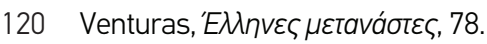

121 Nicolas Manitakis, "Travailleurs immigrés grecs en France, 1916-1931: massification et enracinement d'un mouvement migratoire," in La Diaspora hellénique en France, ed. Gilles Grivaud (Athens: École

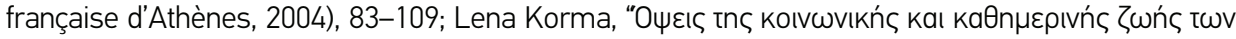

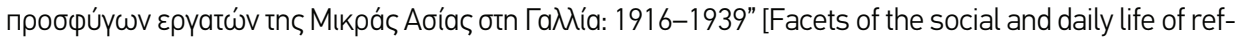
ugee workers from Asia Minor in France, 1916-1939], Archeiotaxio 10 (2008): 25-36.

122 The group of workers sent from Greece to France was comprised of Greeks, Ottomans and Italian nationals. This may be attributed to the fact that, at the time, the Dodecanese were under Italian occupation and, on the other hand, many Greek Orthodox migrants from Asia Minor had taken refuge in Greek and Italian territories after the persecution of 1914, maintaining, however, their Ottoman citizenship. Regarding the legal and administrative issues related to their recruitment, see Korma, "Les réfugiés grecs," 123-50.

123 Paul Thompson, The voice of the past: oral history (Oxford: Oxford University Press, 1978).

124 Philippe Joutard, Ces voix qui nous viennent du passé (Paris: Hachette, 1983).

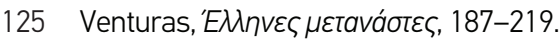

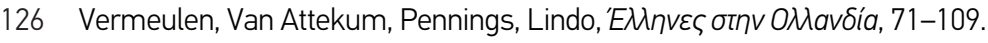

127 Ibid., 81-83.

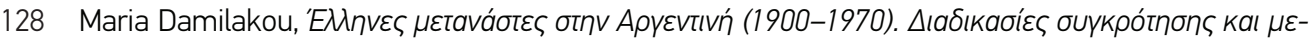

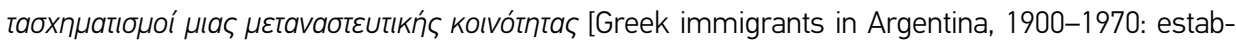
lishment processes and transformations of an immigrant community] (Athens: Commercial Bank of Greece Historical Archive, 2004), 227-72.

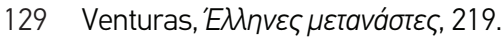

130 Nancy L. Green, "Les juifs étrangers à Paris," in Le Paris des étrangers depuis un siècle, ed. André Kaspi et Antoine Marès (Paris: Imprimerie nationale, 1989), 105-18. 
132 Ibid., 310-317.

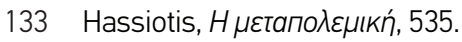

134 Lina Venturas, "'Deterritorialising' the nation: the Greek state and 'ecumenical Hellenism'," in Greek diaspora and migration since 1700. society, politics and culture, ed. Dimitris Tziovas (Farnham: Ashgate, 2013), 131-32.

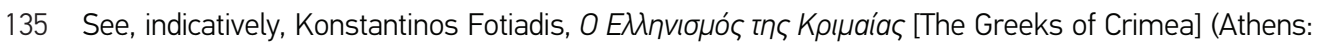

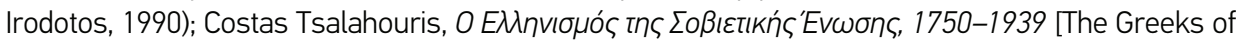

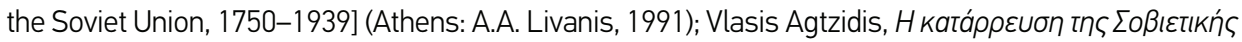

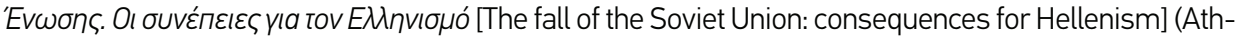

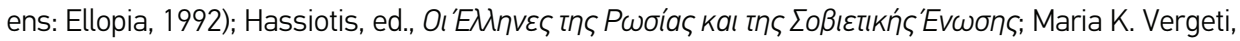

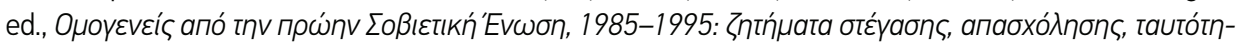
tac [Greeks from the former Soviet Union, 1985-1995: issues of housing, employment, identity] (Thes-

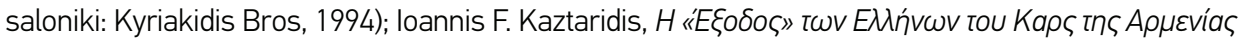
(1919-1921) [The "Exodus" of Greeks from Kars in Armenia, 1919-1921] (Thessaloniki: Kyriakidis Bros,

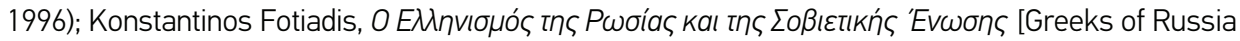
and the Soviet Union] (Athens: Irodotos, 1999).

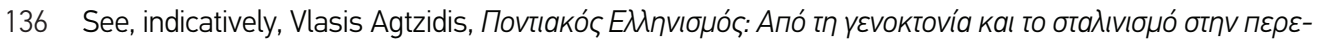
бтрóıka [Pontian Hellenism: from genocide and Stalinism to perestroika] (Thessaloniki: Kyriakidis Bros,

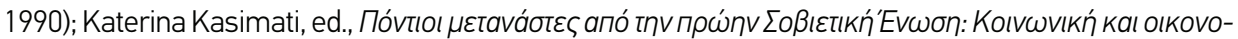
$\mu \iota \kappa n$ touৎ $\varepsilon v t a \xi \eta$ [Pontian immigrants from the former Soviet Union: social and economic integration] (Athens: General Secretariat for Greeks Abroad, 1992); Maria K. Vergeti, Aпó тov Пóvтo бтnv EMáda:

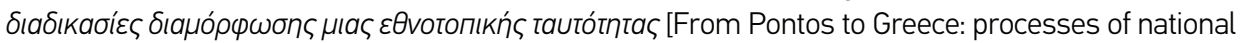
and local identity formation] (Thessaloniki: Kyriakidis Bros, 1994); Vlasis Agtzidis, Пóvtoc. 'Eva avoıxtó Zńtnua [Pontos: an open issue] (Athens: Enallaktikes Ekdoseis, 1996).

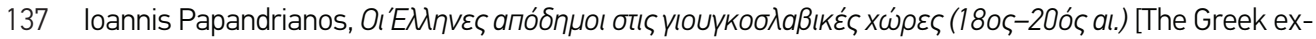
patriates in Yugoslav countries, 18th-20th centuries] (Thessaloniki: Vanias, 1993); Thanos Veremis,

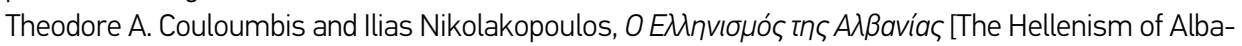
nia] (Athens: Sideris, 1995).

138 See, indicatively, Nicolas Manitakis, "L'essor de la mobilité étudiante internationale à lầge des États-nations. Une étude de cas: les étudiants grecs en France (1880-1940)" (PhD diss., EHESS, 2004); Ma-

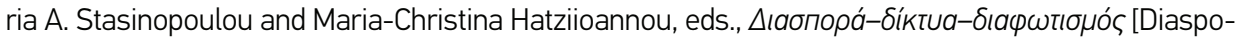
ra-networks-enlightenment] (Athens: Centre for Neohellenic Research/National Hellenic Research

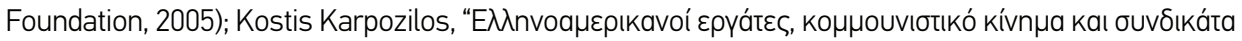

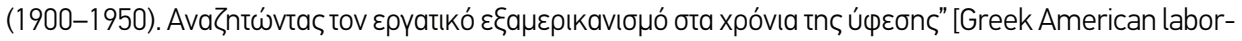
ers, communist movement and trade unions, 1900-1950: investigating the Americanisation of labour in the years of recession] (PhD diss., University of Crete, 2010); Dimitrios Kontogeorgis, "H ع $\lambda$ nvikń

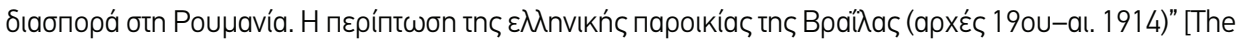
Greek diaspora in Romania: the case of the Greek paroikia of Brăila (early 19th century-1914)] (PhD

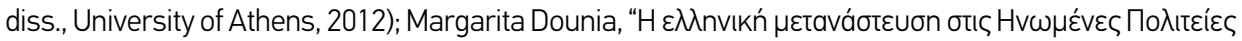

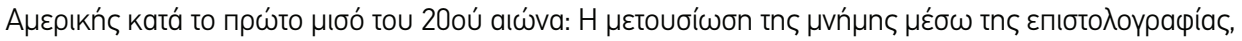

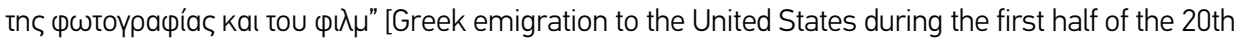
century: preserving memory through letters, photographs and film] (PhD diss., University of Athens,

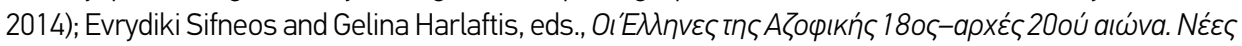

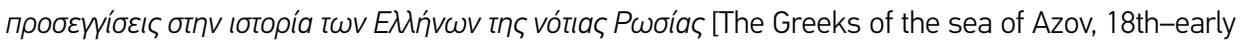


20th centuries. New approaches in the history of the Greeks in southern Russia] (Athens: Institute for Historical Research/National Hellenic Research Foundation, 2015); Dalachanis, Akußźpvntn Пapoıkía.

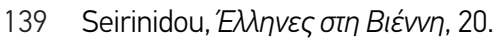

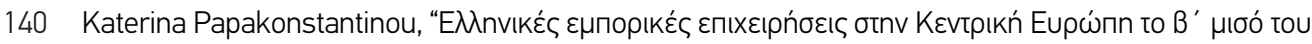

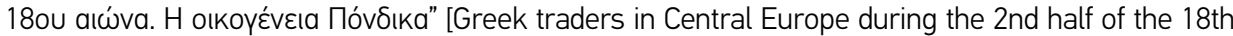
century: the Pondika family] (PhD diss., University of Athens, 2002); Olga Katsiardi-Hering, Texvit

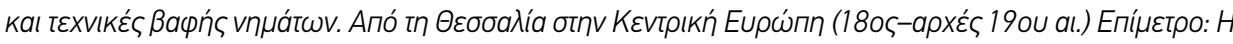

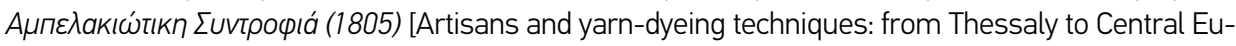
rope, 18th-early 19th centuries. Appendix: the Ampelakia "company" (1805)] (Athens: Irodotos, 2003);

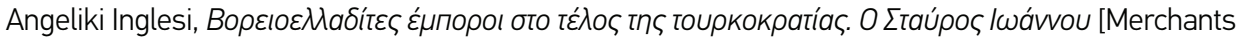
from northern Greece at the end of Turkish rule: Stavros loannou] (Athens: Commercial Bank Histori-

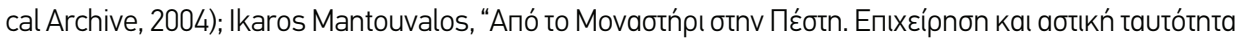

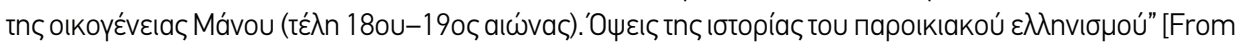
the monastery to pest: enterprise and urban identity of the Manou family (late 18th-19th centuries): aspects of the history of Hellenism in the paroikies] (PhD diss., University of Athens, 2007); Seirinidou,

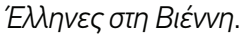

141 Lina Venturas, “État grec et Diaspora. Des «émigrés» à l' «Hellénisme œcuménique»," in Loin des yeux, près du cœur. Les États et leurs expatriés, ed. Stéphane Dufoix, Carine Guerassimoff and Anne de Tinguy (Paris: Sciences Po Les Press, 2010), 239-59.

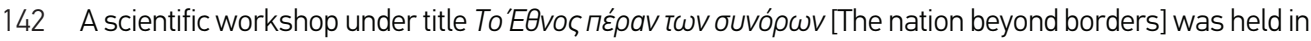
Athens in 2011. If I am not mistaken, it was one of the first collective attempts to study this specific policy. A large number of presentations were included in the volume: Lina Venturas and Lambros Baltsi-

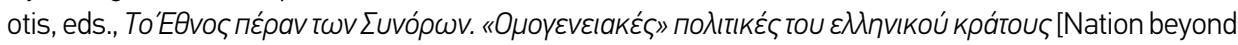
borders: expatriate policies of the Greek state] (Athens: Vivliorama, 2013). Furthermore, with regard to issues of integration and naturalisation, the attitude of the Greek state towards diaspora Greeks and migrants, and the role of the Greek-American lobby, see the second section of Part I in Tziovas, Greek diaspora and migration.

143 Nancy L. Green, Repenser les migrations (Paris: PUF, 2002), 23-35.

144 Ibid., 7-21.

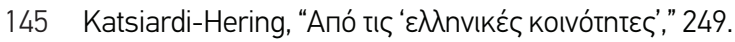

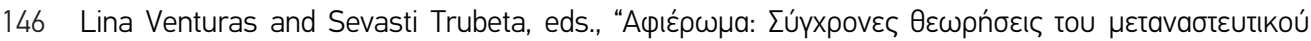

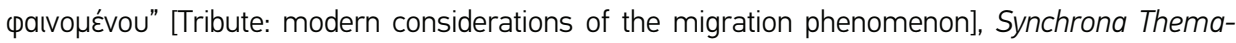

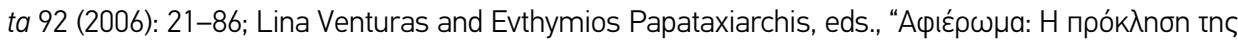

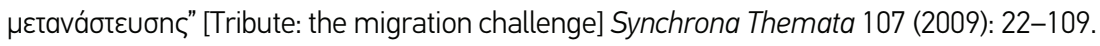

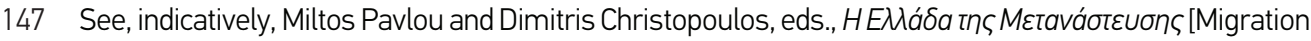
in Greece] (Athens: Minority Groups Research Centre (KEMO), 2004); Vassilis Arapoglou, "Immigration, segregation and urban development in Athens: the relevance of the debate for southern European metropolises," The Greek Review of Social Research 121 (2006):11-38; Lina Venturas, Christos Bakavos

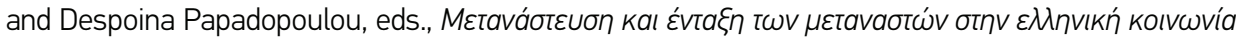
[Migration and integration of immigrants into Greek society] (Athens: Gutenberg, 2006); Evthymios Pa-

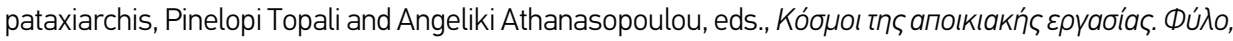

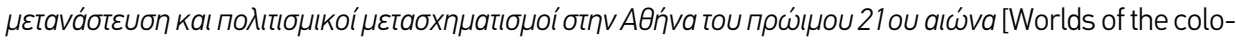
nial work: gender, migration and cultural transformations in Athens of the early 21 st century] (Athens: Alexandria, 2009); Dimitrios Parsanoglou, “Grèce, pays d'immigration: perspectives historiques et so- 


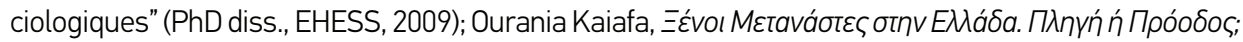
[Foreign immigrants in Greece: plague or progress?] (Athens: Society for the Study of Modern Greek

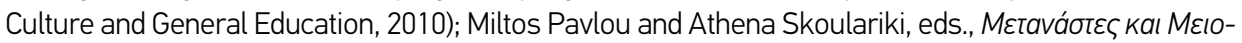

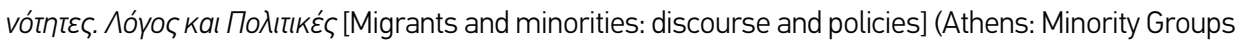
Research Centre (KEMO), 2010); Pierre Sintès, La raison du mouvement. Territoires et réseaux de mi-

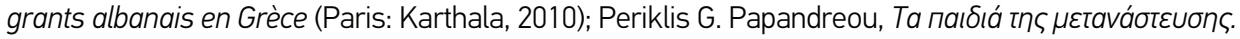

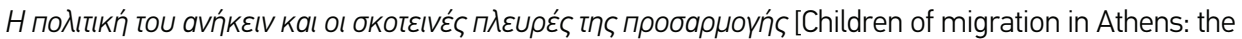
politics of belonging and the downsides of adaptation], trans. Pelagia Marketou (Athens: Nisos, 2013). 